(C2020. This manuscript version is made available under the CC-BY-NC-ND 4.0 license http://creativecommons.org/licenses/by-nc-nd/4.0/

\title{
Counteracting arsenic toxicity: curcumin to the rescue?
}

\author{
Afsane Bahrami ${ }^{1}$, Thozhukat Sathyapalani ${ }^{2}$, Seyed Adel Moallem, ${ }^{3,4}$ Amirhossein \\ Sahebkar ${ }^{5,6,7^{*}}$
}

${ }^{1}$ Cellular and Molecular Research Center, Birjand University of Medical Sciences, Birjand, Iran

${ }^{2}$ Department of Academic Diabetes, Endocrinology and Metabolism, Hull York Medical School, University of Hull, Hull HU3 2JZ, UK

${ }^{3}$ Department of Pharmacodynamics and Toxicology, School of Pharmacy, Mashhad University of Medical Sciences, Mashhad, Iran

${ }^{4}$ Department of Pharmacology and Toxicology, School of Pharmacy, Al-Zahraa University, Karbala, Iraq

${ }^{5}$ Biotechnology Research Center, Pharmaceutical Technology Institute, Mashhad University of Medical Sciences, Mashhad, Iran

${ }^{6}$ Neurogenic Inflammation Research Center, Mashhad University of Medical Sciences, Mashhad, Iran

${ }^{7}$ School of Pharmacy, Mashhad University of Medical Sciences, Mashhad, Iran

Running title: Curcumin and ageing

\section{*Correspondence:}

Amirhossein Sahebkar, PharmD, PhD, Department of Medical Biotechnology, School of Medicine, Mashhad University of Medical Sciences, Mashhad, Iran, P.O. Box: 91779-48564, Iran. Tel:

985138002288; Fax: 985138002287; E-mail: sahebkara@mums.ac.ir; amir saheb2000@yahoo.com

Acknowledgements: None.

Funding: None.

Conflict of interests: The authors declare that no competing interests exist. 


\begin{abstract}
Arsenicosis leads to various irreversible damages in several organs and is considered to be a carcinogen. The effects of chronic arsenic poisoning are a result of an imbalance between pro- and antioxidant homeostasis, oxidative stress, as well as DNA and protein damage. Curcumin, the polyphenolic pigment extracted from the rhizome of Curcuma longa, is well-known for its pleiotropic medicinal effects. Curcumin has been shown to have ameliorative effects in arsenic-induced genotoxicity, nephrotoxicity, hepatotoxicity, angiogenesis, skin diseases, reproductive toxicity, neurotoxicity, and immunotoxicity. This review aims to summarize the scientific evidence on arsenic toxicity in various organs and the ameliorative effects of curcumin on the arsenic toxicity.
\end{abstract}

Keywords: arsenicosis; genotoxicity; oxidative stress; sodium arsenite; turmeric 


\section{Introduction}

Heavy metals are characterized as metallic elements with a relatively high atomic weight such as arsenic (As) which may harm living organisms at small concentrations [1]. As one of the most abundant natural elements and environmental toxicants, As is considered as a critical human health hazard [2]. Various manifestations of chronic As poisoning (arsenicosis) are due to the imbalance between pro- and antioxidant homeostasis and its high affinity for thiol groups on proteins. As is categorized usually as a metalloid, due to its both metallic and non-metallic features [3].

As is ubiquitous in the environment, earth's crust and the biosphere $[4,5]$. Human exposure to As usually occurs by air, soil, drinking water, inhalation, skin contact during occupational situations, contaminated food and medicines [6]. More than 100 million peoples worldwide are exposed to a higher than safe recommended level of As in drinking water as recommended by the World Health Organization $(<10 \mu \mathrm{g} / \mathrm{L})[7]$.

As is water-soluble and exists as elemental (0), trivalent ( +3 oxidation; arsenite), As (III) and pentavalent ( +5 oxidation; arsenate), As (V). When As combines with elements such as oxygen, chlorine and sulfur, it forms the inorganic arsenic (iAs) whereas when it binds with hydrogen and carbon, it forms organic As. Notably, As (III) has been considered to be more toxic compared to As (V) and iAs are more toxic compared to the organic forms (Figure 1) [8-10]. As (V) is an analogue of phosphate and therefore disrupts several pivotal cellular events such as oxidative phosphorylation and ATP synthesis [11]. Arsenate reductase enzyme converts the As (V) to As (III) as a part of detoxification. The half-life of As is nearly 4 days, but As (III) have a lower half-life compared to As (V) [12]. Generally, the bioavailability of iAs is $60 \%$ to $87 \%[13,14]$, and the majority of iAs and its metabolites are excreted through the urine and bile. iAs is easily absorbed by the gastrointestinal tract and after being metabolized in the liver and becomes methylated As. As interferes with several normal body 
activities and affects the central nervous system, reproductive system, the hematopoietic system, cardiovascular system, respiratory system, ophthalmic system and the gastrointestinal system (Figure 2, 3) $[15,16]$.

Arsenicosis causes a myriad of irreversible injuries in several organs in the prenatal period, early childhood and later in life and is considered as a carcinogen. The mechanisms by which As induces carcinogenesis include oxidative stress (OS), DNA damage and chromosomal abnormalities, altering of gene expression and epigenetic modifications [17, 18]. As affects the cellular function of several enzymes, particularly those involved in the heme synthesis and degradation [19]. As compounds have also been implicated in the inactivation of endothelial nitric oxide synthase (eNOS) via connecting with the thiol groups leading to an increase in reactive nitrogen species (RNS) which together with the reactive oxygen species (ROS) causes extensive lipid peroxidation (LPO) and apoptosis [20].

There is a growing interest in establishing a safe and effective treatment for iAs exposure. The use of plant and natural products for the remedy of human diseases is as old as the humankind. The main advantages of medicines based on phytochemicals seem to be their high efficacy, little side effects and a low cost [21]. Curcumin (CUR), the yellowish and water-insoluble polyphenolic pigment extracted from the rhizome of Curcuma longa (Zingiberaceae), is well-known as a pleiotropic medicinal herb [22, 23]. However, there is little known about the protective effects of CUR against hazardous effects induced by the exposure to As, including those associated with damage to the nervous system, DNA, kidneys and liver. The purpose of this review is to summarize the scientific evidence concerning the organ toxicities induced by As, and the ameliorative role of CUR.

\section{Molecular mechanisms involved in arsenic toxicity}

\section{Signal transduction}


As affects the regulation of several cellular signal transduction pathways (Figure 3). As activate a series of downstream signaling cascades and disrupts various signaling pathways associated with cell growth, proliferation and apoptosis [24]. As can damage DNA and triggers the cell arrest at $\mathrm{G}$ or $\mathrm{G} / \mathrm{M}$ phase $[25,26]$. Arsenic trioxide (As2O3) can attenuate the steady-state levels of CDK/cyclin complexes, such as CDK2, CDK6, cyclins A, D1 and E, in different tumor cells [27, 28]. As2O3 arrests the cell cycle by the suppression of cdc2-associated kinase and CDK2/6-associated kinases in compliance with the decreament of cdc25B/C phosphatases and the Rb protein hypophosphorylation, respectively $[27,28]$. It has been found that p53 signaling pathway have a important role in As-created cell cycle arrest [29].

As exposure can induce apoptosis through disturbance of signal transduction, activation of activator protein-1 (AP-1), deactivation of constitutive nuclear factor-kappa B (NF- $\mathrm{B}$ ) and by inhibition of PI3K/Akt signaling. As causes imbalances in intracellular oxidation/reduction reactions which induce signaling axis that modulate early response genes. Transcription factors (TFs) related to stress response, i.e. AP-1 and NF- $\kappa \mathrm{B}$ mediate the transcription of multiple downstream target genes [30]. Since upstream proteins which regulate AP-1, NF- $\mathrm{BB}$, and nuclear factor (erythroid-2 related) factor 2 (Nrf2) and nitric oxide synthase (NOS) all have reactive thiols, their oxidative modification through ROS, produced during As exposure, maybe the crucial step in various cellular responses and toxicity [31]. As stimulate ROS generation, a mitochondrial OS, which in turn decreases the matrix metalloproteinases (MMPs). The disrupted MMP increases the leakage of cytochrome $\mathrm{c}$ and induction of the caspase cascade resulting in apoptosis [32]. 
Mitogen-activated protein kinases (MAPKs) consist of a family of regulatory serine/threonine phosphorylating proteins which regulate the signal transductions against different extracellular stimuli and mediate the regulation of gene amplification, mitosis, motility, metabolism, and apoptosis [33]. The MAPK family encompasses important members such as extracellular signal-regulated kinases (ERKs), c-Jun amino-terminal kinase 3(JNK) and p38 [33]. ERKs transduce the signaling which causes cell differentiation, proliferation and transformation, whereas JNKs and p38 kinase react to stressful events, which leads to the cell cycle arrest and cell apoptosis [34]. As has an impact on various biological pathways since it can induce proteins such as ERK2, p38 and JNK [35-37]. Thereore, the Ras-MAPK/ERK pathway seems to be sensitive to As damage [38].

Many family members of receptor tyrosine kinase (RTK), have emerged as a main regulators of important cellular processes, like cell proliferation, differentiation, metabolism, survival, propagation, and cell-cycle control [39]. Exposure of the cells to As promoted total cellular tyrosine phosphorylation possibly through direct interact with EGFR molecules to induce the conformational changes or the dimerization of EGFR, and eventually EGFR activation [40]. As might activate EGFR via the production of ROS which stimulated the conformational altrations in the receptor [41]. As exposure also produces dose-dependent toxicity through stimulation of epidermal growth factor receptor (EGFR) pathway intermediates, cSrc, Rac1, Shc, Grb2, MAPK or ERK kinases (MEK)1/2 and ERK1/2 [42, 43]. As-mediated ERK1/2 induction reversely regulates DNA polymerase beta expression and over-expresses heme oxygenase $1(\mathrm{HO}-1)$ at toxic concentrations [42]. As also can induce carcinogenesis and can promote tumor growth [44]. Generally, the ERK1/2 cascade is activated by mitogens like growth factors. Aberrant regulation of the ERK 12 cascade can cause susceptible cells to undergo tumorigenesis [42]. As induces tumorigenesis also through 
the abrogation of p53 pathway causing uncontrolled proliferation [24]. Evidence also suggests a connection between As exposure and inhibited acetylcholinesterase (AChE) activity [45], generation of acetylcholine (ACh) and action of choline acetyltransferase [46]. The protein kinase $\mathrm{C}(\mathrm{PKC})$ family includes different isoenzymes with identical structures; all of which regulate various cellular actions. Three known PKC forms (PKCa, PKCE, and $\mathrm{PKC}$ ) were found to mediate As-induced cellular signal transduction resulting in AP-1 induction [47]. As induced translocation of PKC isoforms from the cytosol to membranes, where these isoenzymes mediate As-induced AP-1 activation via various MAPK (ERKs, JNKs, and p38) pathways [47].

Autophagy flux disturbance has also been observed in As models. Sodium arsenite (NaAsO2) causes to an accumulation of LC3-II and p62 proteins in female mice. The LC3-II is an crucial protein for elongation and fold of the phagophore in the autophagosome membranes. Whereas, p62 is a receptor protein, which binds to the specific cargo, eventually leads to the cargo's degradation whitin autophagolysosomes [48, 49]. The This phenomenon is related with ERK overinduction, via SOCS3-dependent IL-6/STAT3 signaling cascade inhibition [50].

Angiotensin II Type I receptor $\left(\mathrm{AT}_{1} \mathrm{R}\right)$ as a $\mathrm{G}$ protein-coupled receptor coordinate most of the physiological or pathological roles of AngII as a part of renin-angiotensin system [51, 52]. $\mathrm{NaAsO} 2$ increases the expression of $\mathrm{AT}_{1} \mathrm{R}$ by ROS-mediated induction of the JNK pathway. Long-time As exposure can enhance the pathogenic roles of AngII via modulating a deviant $\mathrm{AT}_{1} \mathrm{R}$ signaling pathway, resulting in hypertension [53].

\section{Receptor pharmacology}

As can disrupt the hormone-induced gene expression mediated via the glucocorticoid receptor (GR) [54]. Glucocorticoids activate a different biological process that is mediated 
via their connection with the cytosolic steroid hormone receptor GR. GR coordinates various metabolic and homeostatic functions in almost all tissues [55]. It has been shown that non-toxic concentrations of As can interact directly with GR complexes and specifically inhibit GR-mediated transcription [56].

It has been shown that As can cause male infertility by suppression of androgen receptor (AR) transcriptional activity via inhibiting the recruitment of AR to promoters of its target gene [57]. As have also been found to be an active endocrine disruptor of estrogen receptor (ER)-mediated gene expression, both in vivo and in vitro [58].

As can also interrupt the function of the hypothalamic-pituitary-adrenal (HPA) axis. As increases serum corticosterone concentrations, decreases levels of corticotropin-releasing factor receptor 1 in offspring hippocampus, and raises dorsal hippocampal serotonin 5-hydroxytryptamine receptor as well as receptor-effector coupling [59]. It has been reported that As (III) affects thyroid hormone levels and interrupts thyroid function via alterings the expression of TR-associated genes. As exposure change the expression of thyroid hormone receptor (TR) response element as well as the endogenous TR-regulated type I deiodinase gene [60].

The transient receptor potential melastatin 4 (TRPM4) is a voltage dependent non-selective cation channel [61]. TRPM4 is mainly found in the heart, and CNS, as well as its expression also found in endothelial cells (ECs) from various vascular tissues [62]. As2O3 over-express the both transcription and translationsl levels of TRPM4 through entering the cell membrane, TRPM4 channels is over-activated in endothelial cells (ECs). The activated TRPM4 channels causes to unlimited $\mathrm{Na}^{+}$influx which leads cell membranes depolarization and $\mathrm{Ca}^{2+}$ overload, eventually the ECs are injuried [63]. 


\section{Biochemistry}

As can substitute phosphate in various biochemical reactions due to their identical structure and characteristics [64]. For instance, arsenate interacts with glucose and gluconate [65] to generate glucose-6-arsenate and 6-arsenogluconate, respectively. These elements are similar to glucose-6-phosphate (G6P) and 6-phosphogluconate, respectively. During the glycolysis, glucose-6-arsenate is a substrate for glucose-6-phosphate dehydrogenase (G6PD) and can suppress hexokinase, as does G6P $[66,67]$.

The metabolomic investigations demonstrated that alteration in the metabolism of energy, amino acid, purine, choline as well as degradation of membrane phospholipids is implicated in the cell apoptosis in As-induced toxicity [68]. As enforces allosteric inhibition of pyruvate dehydrogenase complex which catalyze the oxidative decarboxylation of pyruvate to synthesis acetyl-COA via NAD+. Therefore, the cellular energy system is disrupted and results in apoptosis [12]. The As toxicity could be via its interaction with sulfhydryl groups related to proteins and enzymes and via boost of the ROS in the cells leading to cell damage [69]. In addition, As activate unstable mitochondrial metabolism, reduced withdrawal of ROS, attenuate protein production and changing membrane lipid polarity and fluidness resulting in the mitochondrial oxidative injury [70].

Furthermore, As can also lead to thiamine deficiency through mitigating its availability and also cause lactic acidosis via increasing the amount of lactic acid [12]. $\mathrm{NaAsO} 2$ increased LPO, DNA fragmentation, triacylglycerides, total cholesterol and low-density lipoprotein cholesterol (LDL-C), while antioxidant status and high-density lipoprotein cholesterol (HDL-C) were found to be decreased [71]. 
As regulate the expression of the heat shock proteins (Hsps) families. Hsp are regulated via a complex regulatory mechanism, which needs the integration of most signal pathways. This stress response is an adaptive phenomenon in organisms [72]. For instance, Hsp90 is involved in the regulation of cellular redox status. Redox-regulated communications between cytochrome c and cytoplasmic Hsp90 are implicated in apoptosis. These interplays can be inhibited by high doses of $\mathrm{NaAsO} 2$ in a purified system [73].

\section{Immunity}

As has been shown to lead immunotoxicity, skin lesions and suseptibility to developing malignancy (Figure 3)[74, 75]. In difernent experimental model, As exposing has been found to attenuate $\operatorname{IgM} / \operatorname{IgG}$ antibody-forming cell response $[76,77]$ as well as repress delayed type of hypersensitivity response to phytohemagglutinin [78]. $\mathrm{NaAsO} 2$ can change immune cell populations causing to functional altrations in immune response particularly decreament of cutaneous contact hypersensitivity response [79].

Immunosuppressive features of As lead to inability of innate immune system to eradicate various bacterial and viral infection such as HIV-1 [80] and influenza A (H1N1) infection[81]. In Bangladesh, people who expose to As, more vulnerable to lower respiratory tract infections and diarrhea [82-84]. Neutrophil and macrophages as a main regulator of innate immunity have been reported to be a major cellular target population of As toxicity[85, 86]. For instance, As prompts apoptotic cell death in neutrophils and change phenotype of Macrophages. Remarkable loss of cell adhesion capability, reduce NO generation, and reduce chemotactic/phagocytic dysfunction and reduced regulation of CD54/F-actin with these immune cells [87-89]. iAs inhibits the differentiation of monocytes to functionally active macrophages through suppressing survival signaling pathways [90]. Additionally, As can alters the phenotypic and genotypic properties 
of mature macrophages [87, 91, 92]. iAs significantly changes the expression of a large number of correspounding genes particuarly activated or inhibited whitin the differentiation process, possibly via an oxidative stress-associated mechanism [91, 92]. Indeed, As also mitigate cystic fibrosis transmembrane conductance regulator (CFTR)-mediated chloride secretion; so abolished clearance of respiratory pathogens [93].

There are remarkable negative correlation between long-time As exposure and the number and action of T regulatory cells in adults [94]. It has been shown that maternal As exposure during pregnancy was related with a reduction in the frequency of pan T cells in the placenta in spite of increased inflmmatory cytokines amounts, as well as reduced thymic size and function in infants and elevated morbidity from infectious diseases[84, 95, 96].

iAs can also markedly alter development, induction and proliferation of $\mathrm{T}$ cells [97]. Actually, iAs-dependent suppression of peripheral $\mathrm{T}$ cell proliferation is mainly related with inhibition of interleukin-2 (IL-2) secretion which is necessary cytokine for induction of T cells and their progression to the cell cycle [98]. As2O3 enormously impaires the releasing of IL-12 and IL-23 from activated dendritic cells and reduce the activation of T helper (Th) cells $[99,100]$. Altogether, these evidences indicated that As may change both the action and the number of T cells, which are of important for cell-mediated immunity $[90,101]$.

\section{Curcumin}

Curcumin [1,7-bis(4-hydroxy-3-methoxy phenol)-1,6-heptadiene-3,5-dione], is an alkaloid and the active component of turmeric and ginger [102]. Since at least 2500 years ago, turmeric root has been extensively used to add color and flavor in cooking and as a remedy in traditional medicine. CUR showed various biological advantageous such as anti-microbial, antioxidant, lipid-lowering, hypoglycemic, anti-inflammatory and anti-ageing properties [103-108]. Molecular targets of CUR are numerous including transcription factors, 
transporters, enzymes, microRNAs, pro-inflammatory cytokines, apoptotic proteins, growth factors, hormones and receptors [109-113].

CUR as a chain-breaking antioxidant which gives $\mathrm{H}$ from the phenolic moiety [114]. The aromatic ring systems (phenols) are linked via 2 , $\beta$-unsaturated carbonyl groups. Furthermore, CUR can inhibit LPO and quenching hydroxyl and superoxide radicals through the phenolic $\mathrm{OH}$ group and the $\mathrm{CH} 2$ group of the $\beta$-diketone section $[115,116]$. Multiple molecular targets in different cell types, i.e. NF-kB, P38, hypoxia-inducible factor (HIF-1 $\alpha$ ), peroxisome proliferator-activated receptor- $\gamma(\operatorname{PPAR} \gamma)$ and AKT, are involved in the anti-inflammatory effect of CUR $[117,118]$.

In another pathway, CUR exerts anti-oxidative functions through activation of antioxidant responses via Nrf2 activation and effectively suppresses a host of factors which contributes to inflammation [119]. CUR can decrease the expression of genes implicated in apoptosis, proliferation, and transformation [120].

CUR reduces N-nitrosodiethylamine (DEN)-caused hepatotoxicity by modulating the enzymes involved in the oxidant stress, liver function, lactate dehydrogenase A (LDHA), alpha-fetoprotein (AFP) and the cyclooxygenase (COX)-2/Prostaglandin E2 (PGE2) cascade [121]. CUR has been shown to have ameliorative effects in the As-induced genotoxicity [122, 123], nephrotoxicity [124], hepatotoxicity [125], angiogenesis [123], dermatological disorders [126], reproductive intoxication [127], neurotoxicity [128] and immunotoxicity (Figure 4) [129]. It has been reported that CUR also can used as a co-treatment with chelating agents in a synergistic way for the treatment of As intoxication[130].

\section{Effect of curcumin on arsenic-induced toxicity}

\subsection{Nephrotoxicity}


Acute tubular necrosis with acute renal failure has been observed in patients with acute As poisoning. Some of these cases can progress to cortical necrosis and ultimately chronic kidney disease. The kidney injury can be due to the hypotensive shock, direct impacts of As on tubule cells resulting in tubular damage and hemoglobinuria or myoglobinuria which can lead to proteinuria. Acute tubulointerstitial nephritis has also been considered as a clinical presentation of acute As intoxication [131].

$\mathrm{NaAsO} 2$ causes shrinkage of the glomerulus, disturbed glomerular integrity, and a reduction in the glomerular area as well as an increase in the Bowman's space due to the of glomerular atrophy. Collagen is the important protein ingredient of glomerular basement membrane and is necessary for glomerular integrity [132]. As affects cell antioxidant defense system to activate LPO and the disturbance of cell polyunsaturated fatty acid. As also suppress protein synthesis [133]. Simultaneous treatment with CUR plus $\mathrm{NaAsO} 2$ ameliorated the side effects of As on the glomerulus and proximal tubule, glomerular area, serum total antioxidant capacity and the circulating levels of malondialdehyde (MDA) [134]. It has been shown that CUR reduced the As-induced increase in bilirubin, urea and creatinine $(\mathrm{Cr})$ in an experimental model of As toxicity $[46,135,136]$. The elevated amount of serum Cr after As2 33 exposure is because of the increased formation of metabolic waste product related to metabolism of musclse. Moreover, $\mathrm{Cr}$ is anhydride of creatine. Muscle consists phosphocreatine which endores involuntary cyclization with miss of inorganic phosphorous to constitute creatine. Transformation of creatine into $\mathrm{Cr}$ is a non-enzymatic immutable procedure. Since, affinity for thiol group of different proteins exist in the cell membrane of muscles, As harms the cells due to which the enzyme, creatine phosphokinase, released from the cells which is acounted for the transformation of phosphocreatine in to creatine. Therefore enhances the value of $\mathrm{Cr}$ [137]. Ameliorative role of CUR against As induced pathologies could be due to the antioxidant potency of this natural agent. The protective roles of Curcuma 
aromatica leaf extract were shown on the nephrotoxicity of As2O3 in the albino rats. As2O3 poisoning significantly increased the serum level of uric acid, blood urea nitrogen, and $\mathrm{Cr}$ because of renal dysfunction. Curcuma aromatica $(50 \mathrm{mg} / \mathrm{kg} \mathrm{BW})$ normalized the serum levels of uric acid, blood urea nitrogen and Cr [137]. Curcuma aromatica inhibits tubular necrosis and back-leak of filtrate as well as normalize serum urea consentration by antioxidant features [137].

OS is a hallmark of As-induced liver, renal and neuronal injury [138]. As is not a redox metal, however, is a potent disruptor of the cell signaling pathways through inducing reactive oxygen and nitrogen radical production, where superoxide anion radical is the main species that is turned to hydrogen peroxide and finally to hydroxyl radical [139]. Hydroxyl radical can interact with macromolecules resulting in OS, LPO, DNA damage and extensive changes in the cellular regulatory mechanisms [139-141].

Several enzymatic antioxidants such as superoxide dismutase (SOD), catalase (Cat), glutathione peroxidase (GPx), glutathione reductase (GR), glutathione-S-transferase (GST) and G6PD are the first line of intracellular defence against OS induced by As exposure [142]. SOD and Cat are considered to be the two preliminary subcellular defence of antioxidant system against free radical production with As exposure. SOD catalysis the conversion of superoxide anion to hydrogen peroxide $(\mathrm{H} 2 \mathrm{O} 2)$, whereas Cat or GPx converts $\mathrm{H}_{2} \mathrm{O}_{2}$ to a water molecule. Glutathione (GSH) associated enzymes such as GPx and GR acts directly or indirectly against oxidation, but GST is also involved in the metabolic detoxification. GSTs maintain a shield against As via conjugation or decrement with GSH as well as relief the OS and subsequent LPO induced by As [143]. GST and GPx decrease the organic hydroperoxides in the membranes and lipoproteins accompanied by GSH. GSH as a tripeptide non-enzymatic antioxidant has a crucial role in the free radical quenching and acts as a co-factor for numerous enzymes participating in the general antioxidant defence [144]. In 
addition, GSH inhibits the oxidation of SH-groups [145]. Hence, these antioxidant enzymes reduce the deleterious effects of ROS.

The protective role of CUR against As could be through free radical scavenging, which would inhibit the oxidation of SH-group (Figure 4) [146]. The renoprotective effect of CUR is due to the scavenging of ROS and inhibition of hydrogen peroxide-induced oxidative injury in a renal cells [147]. Furthermore, CUR can potentially inhibit the thiol depletion and improves the renal GSH amount [136]. Thiols (SH-group) considered to be a main protector of cells against ROS. Furtheremore, thiols as a target site for As-induced cellular injuary can remarkably decrease SH-group content. CUR enhances the activities of antioxidant enzymes (SOD, Cat, GSH, GR, GPx, and GST). Simultaneous administration of $\mathrm{NaAsO} 2$ with CUR decreased the levels of thiobarbituric acid-reactive substances (TBARS), whereas augmented the actions of the antioxidant enzymes, and the amount of SH-groups [148].

Sankar et al. reported that As exposure through drinking water (25 ppm; 42 days) led to OS and tissue injury in kidneys of rats. However, nanoparticle-encapsulated CUR (NP-CUR) treatment remarkably increased the GSH level (60\%), GR function (67\%) in kidneys as well as reduced the LPO in the rats exposed to As [135].

\subsection{DNA damage}

As is categorized as a group 1 human carcinogen as per the epidemiological surveys [15]. It has been shown that As have genotoxic effects such as induction of OS, enhancing the number of micronucleus (MN) and chromosomal aberrations, DNA strand break, cross-links between DNA and protein, reduction of proliferation index, suppression of DNA repair along with production of 8-hydroxy-20-deoxyguanosine (8-OHdG) as an indicator of OS to DNA caused by As [149-151]. The ROS-related DNA damage 8-oxoguanine is removed through 8-oxoguanine DNA glycosylase, which encodes through $O G G 1$ gene. It has been shown that OGG1 gene expression is significantly associated with chronic exposure to As [152]. As 
prevents the enzymes contributed in repair, so causing to the change of DNA replication and repair mechanisms. Suppression of DNA is because of the inihibitory effect of As (III) on DNA ligase II/I [153]. As (III) can produce NO to damage DNA, which thus induce ADP-ribosylation [153].

CUR has a protective effect against the As-induced DNA lesions through combating ROS production and LPO, promotion the activities of numerous antioxidant enzymes, i.e. Cat, SOD, GPx, GR, GST and GSH [122]. CUR also induces over-expression of the polymerase, an enzyme responsible for DNA repair [153].

In another study, CUR effectively restored the genotoxic effect of As by decreasing the number of structural aberrations and hypoploidy (Figure 4) [154]. CUR also suppressed the 8-OHdG and $O G G 1$ regulation and activated the DNA repair enzymes in the repair pathways at the protein and gene levels [155]. The protective effects of CUR against As-induced genotoxicity may be due to its antioxidant and free radical scavenger properties [156]. CUR can trap the free radicals and induce O6-methylguanine-DNA methyltransferase (MGMT), a protective genome protein $[157,158]$, and $\mathrm{HO}-1$ activity which donates $\mathrm{H}$ from phenolic $\mathrm{OH}$ group and suppresses the iNOS induction resulting in protection of DNA [159]. Biswas et a.l. reported that treatment of Swiss albino mice with CUR prevented the NaAsO2-induced DNA lesions through decreasing the comet tail moment of whole blood and $\mathrm{MN}$ population in the cultured splenic lymphocytes [160]. Findings of in vitro and the field trials among Indian populations exposed to chronic groundwater As demonstrated that $\mathrm{NaAsO} 2$ can induce DNA damage and generates ROS which was efficiently ameliorated by CUR [161].

\subsection{Neurotoxicity}

Metals can cross the blood-brain barrier (BBB) and deposit in the brain resulting in neurobehavioral disorders [162]. Deposition of As in the central nervous system impairs the neuronal activities, reduces the neuronal migration, prevents the neural progenitor cells 
proliferation and maturation together with altered dopaminergic, cholinergic, serotonergic and glutamatergic systems functions [162-164]. Children who are chronically exposed to As have difficulties in cognitive development and verbal intelligence $[165,166]$. As related-neurotoxicity occurs by the promotion of apoptosis via activating p38 mitogen-activated protein kinase and JNK3 pathways along with activation of caspase-9, an initiator of apoptosis [167]. Degenerative lesions and vascular engorgement was found in brain tissues demonstrate the possible of the As to enforce neurotoxicty. As-induced production of free radicals and following OS is one of the main mechanisms which mediate conversion in these tissues [168]. Although, brain is more sensitive to As due to that has an inefficient oxidative system [169]. Additionally, brain possess a high levels of polyunsaturated fatty acid [170].

CUR can inverse neuroleptic-created tardive dyskinesia in rats [171]. CUR also exhibited significant neuroprotection in focal cerebral ischemia via suppressoing of LPO and regulating antioxidant enzymes [172]. It was also reported to be has potential in decreasing the peroxynitrite generation in cerebral ischemia [173]. A decrease in As amounts in brain tissues, CUR [174] that may have possibly reduced the load of As.

Accumulating evidence suggests that As-induced neurotoxicity is neutralized by CUR through modulating the OS and dopaminergic functions. NaAsO2 $(20 \mathrm{mg} / \mathrm{kg} \mathrm{BW})$ reduce the levels of dopamine $(28,51$ and 35\%), norepinephrine (54, 22 and 35\%), epinephrine $(46,47$ and 29\%), serotonin (44, 25 and 54\%), 3,4 dihydroxyphenylacetic acid (20, 34 and 37\%) and homovanillic acid (31, 41 and 46\%) in the corpus striatum, frontal cortex and hippocampus, respectively. CUR can modulates the levels of $\mathrm{NO}$ and brain biogenic amines in As-contaminated rats [128].

$\mathrm{NaAsO} 2(20 \mathrm{mg} / \mathrm{kg} \mathrm{BW})$ and CUR (100 mg/kg BW) therapy led to an increased locomotor function and grip force as well as promoted the rota-rod task in As treated rats. A remarkable 
improvement in behavioral, neurochemical and immunohistochemical indices in the rats which concurrent received As and CUR demonstrates the neuroprotective potential of CUR [163]. CUR potentially crosses the BBB and reduce senile plaques and cerebrovascular amyloid angiopathy as well as decreases amyloid accumulation and neuroleptic-created tardive dyskinesia [171, 175]. Jahan-Abad and coworkers provided evidence on the preventive effect of CUR combating the toxic effects of As on the viability, telomerase activity and cell death of neural stem cells [176]. CUR effect on elevating telomerase activity might be mediated via upgrading the stability of telomerase structure and successively enhancing the halflife of the enzyme [177]. Cell damage/death in As-treated neural stem cells happen via caspase-dependent apoptosis and CUR attenuated caspase processing[176]. As can also induce white matter lesions and damage the brain hippocampal CA1 area. Co-treatment with antioxidants (N-acetylcysteine and CUR) reverse these changes and protect cells against inflammation through decreasing the levels of MMP-2, -9 and TNF- $\alpha$ inflammatory factors[178].

It has been shown that As can disturb the maturity of the pre- and post-synaptic signaling proteins related to the dopaminergic axis in the corpus striatum. The concurrent exposure to CUR led to the amelioration of the As-induced changes in the regulation of DAD2 receptors, pPP1 $\alpha$, PKA, pCREB and pDARPP32. Moreover, modulation in the regulation of pGSK3 $\beta$ and BDNF in the corpus striatum via CUR demonstrates the significance of the neuronal survival cascade in As-stimulated dopaminergic dysfunction [179]. In similar in vivo and in vitro experiment, administration of CUR alleviated the $\mathrm{NaAsO} 2$-induced variances in the levels of N-methyl-D-aspartate (NMDA) receptors and its subunits along with synaptic proteins (pCaMKIIa, PSD-95 and SynGAP). CUR also compensated for the NaAsO2-induced reduction the levels of pAkt, pGSK3 $\beta$, pERK1/2, BDNF and pCREB. Interestingly, CUR exerts its neuroprotective effects against $\mathrm{NaAsO} 2$ in the hippocampus via 
regulating PI3K/Akt/GSK3 $\beta$ pathway [180]. As-induced decreament in brain acetylcholinesterase action were also observed to be mitigated after CUR treatment in rats [46].

$\mathrm{NaAsO} 2(5 \mathrm{mg} / \mathrm{kg} \mathrm{BW})$ remarkably mitigated the function of the brain and plasma $\mathrm{AChE}$ and levels of plasma total protein, albumin and HDL-C, while increased the levels of urea, $\mathrm{Cr}$, bilirubin, cholesterol, total lipid, LDL-C, triglyceride and glucose which were reversed by the administration of CUR (15 $\mathrm{mg} / \mathrm{kg} \mathrm{BW})$ in rats [46].

\subsubsection{Cholinergic dysfunctions}

As exposure possibly lead to cholinergic dysfunctions linked with the activity of the brain AChE and disturbed learning and memory in experimental models $[181,182]$. It has been reported that iAs has major effects on brain primary cultures obtained from transgenic Tg2576 mice, which increased the expression of amyloid precursor protein (APP) and are associated to the early development of Alzheimer's disease (AD)[183]. Chronic As exposing induces the JNK3 and p38 MAPK related with the construction of neurotic plaques (NFs) and neurofibrillary tangles(NFTs) [184] which are associated with the AD [185]. It has been shown that CUR can reverse As-induced brain cholinergic deficits [186]. CUR decreased the vasoactive peptide endothelin1-created cell death of hippocampal neurons through diminishing of cleaved caspase- 3 , decreament the activity of caspases $3 / 7$ via inhibiting the elevation in c-Jun amounts [187].

Concurrent supplementation of rats with NaAsO2 (20 mg/kg BW) and CUR (100 mg/kg BW) enhanced the learning and memory execution related with the over binding of $[3 \mathrm{H}]$ quinuclidinyl benzylate $([3 \mathrm{H}]-\mathrm{QNB})$ and the activity of $\mathrm{AChE}$ in the hippocampus and frontal cortex versus the As group. An increase in the transcription, translation and immunoreactivity of choline acetyltransferase, an index of cholinergic neurons, as well as 
binding of cholinergic-muscarinic receptors (MAChR), Nissl-stained hippocampus was also observed in the As+CUR than As group [186].

Similarly, treatment with both As $(20 \mathrm{mg} / \mathrm{kg} \mathrm{BW})$ and CUR $(100 \mathrm{mg} / \mathrm{kg} \mathrm{BW})$ protected against the alterations in the mitochondrial membrane integrity, function of mitochondrial complexes and a reduction in the CHRM2 receptor gene in specific brain regions of rats along with regulating the amplification of brain pro- and anti-apoptotic proteins which are induced by As [188].

\subsection{Hepatotoxicity}

The liver is the most common site for the metabolism and methylation of As [189]. The As methylated metabolites produced in the hepatocytes, methylarsinic acid (MMA) and dimethylarsinic acid (DMA), are primarily excreted through urine as a detoxification and elimination system (Figure 2, 3) [190]. Furthermore, the liver is also considered as one of the main targets of As toxicity. Histopathological changes in the liver tissue, abnormal liver function tests with gastrointestinal manifestations and an increase in serum enzymes are frequent during acute and chronic arsenicosis [191, 192]. It has been shown As intoxication remarkably discharge delta-aminolevulinic acid dehydratase (ALAD) activity in liver tissues of mice [193]. It has been suggested that the leakage of enzymes due to the liver damage is prohibited through the liver cell membrane stabilizing activity of CUR. It has been shown that CUR potentially can enhance the As methylation and excretion through urine [125]. Due to its polyphenolic structure and $\beta$-diketone functional group, CUR has powerful antioxidant potencies compared to other flavonoids with only one phenolic hydroxyl group [194].

As2O3 administration causes the production of reactive ROS, As accumulation, and attenuation of various antioxidant enzymes in the liver of adult male Wistar rats. CUR administration $(15 \mathrm{mg} / \mathrm{kg} \mathrm{BW})$ had hepatoprotective effects from the As induced-worsening of antioxidant levels and OS. CUR also led to a remarkable reduction in the hepatic As 
accumulation and serum marker enzymes including aspartate transaminase (AST), alanine transaminase (ALT) and ALP [195]. CUR administration also (0.4 mg/kg BW) significantly reduced the intracellular ROS generation via promoting the activity of GR and ROS scavenging enzymes (GST, GPx, SOD and Cat) in the hepatic tissue of adult male Swiss Albino Mice exposed to As2O3 [127]. Similarly, As-induced elevation of serum ALT and AST, hepatic MDA, as well as the decrements of serum and hepatic GSH concentrations were all also reversed by administration of CUR[125].

In another study, for enhancing the bioavailability of CUR, encapsulated CUR in chitosan nanoparticles (ECNPs) have been shown to have a superior antagonistic effect against As-induced toxicity than free CUR. Co-treatment with CUR or ECNPs with As significantly ameliorated the alterations in the hepatic OS markers. As exposure led to ROS generation and an increase in LPO, which was significantly reduced after CUR administration [196]. Sankar et al. studied the efficacy of the NP-CUR from $\mathrm{NaAsO} 2$-related hepatic oxidative injuries in rats. Hepatotoxicity of As was manifested by an elevation of the serum ALT and AST activities and led to related histological changes in the liver. As elevated LPO and reduced the activities of SOD, Cat, GPx and GR in the liver. CUR administration resulted in a significant improvement of the As-induced effects and to a greater extent by CUR-NP. These findings imply that when CUR given in a nano-encapsulated form has better efficacy on As related toxicities compared to free CUR[197].

CUR reduced the toxic biochemical responses of As through lowering the acid phosphatase activity (43-70\%), alkaline phosphatase (ALP) activity (40-63\%) and GSH activity $(27-41 \%)$ as these enzymes are markers for As-induced toxicity in Swiss Albino Mice [198].

Recently, CUR has been suggested to have chemopreventive effects via the induction of Nrf2. NF-E2 related factors (Nrfs) are a group of transcription factors which modulate the 
cellular stress response to OS via the $c i s$-acting antioxidant response element (ARE). Usually, ARE-dependent genes are responsible for mediating the redox homeostasis of cells and inhibit oxidative injury. Under OS, Nrf2 and/or Nrf1 bind and activates the expression of detoxifying genes [199]; NAD(P)H:quinone oxidoreductase 1 (NQO1), GSTs, Gama-glutamylcysteine synthetase heavy subunit $\left(\gamma-G C S_{h}\right)$ and light subunit, HO-1, glutamate-cysteine ligase catalytic $(G C L C)$ and regulatory $(G C L M)$ subunits, and peroxiredoxin 1 [200].

It has been shown that the effects of CUR against the As-induced hepatic damages are potentially mediated through activation of the Nrf2 pathway. Post CUR administration, both the hepatic Nrf2 protein and two primary Nrf2 downstream genes including NADP(H) quinine oxidoreductase 1 (NQO1) and HO-1, were over-expressed. Considering the potent antioxidative and detoxifying capacities of HO-1 and NQO1, their up-regulation may, in turn, reduce the As-induced OS [125].

$\mathrm{NaAsO} 2$ reduces the cell viability and induction of apoptosis via an increase in the number of cells with ROS generation, loss of mitochondrial transmembrane integrity, changing the function of cytochrome c oxidase and citrate synthase, increasing the cell population with sub-G1 DNA content and DNA fragmentation in murine splenocytes. Co-treatment of CUR with $\mathrm{NaAsO} 2$ resulted in a significant improvement in cell viability and attenuation of the As induced apoptosis-associated molecular alterations [201].

Tetrahydrocurcumin (THC), one of the main metabolites of CUR, in certain biosystems, was shown to have a higher antioxidant function compared to CUR. Muthumani and co-workers administrated As $(5 \mathrm{mg} / \mathrm{kg} \mathrm{BW})$ with THC $(80 \mathrm{mg} / \mathrm{kg} \mathrm{BW})$ for 28 days in a rat model. As treatment-induced hepatotoxicity as evidenced by elevated activities of serum AST, ALT, ALP and bilirubin as well as worsened the lipid peroxidative parameters, TBARS. As also worsened serum lipid levels, reduced the antioxidant activities of SOD, Cat, GPx and GSH 
along with mitochondrial enlargement, suppression of cytochrome c oxidase, Ca2+ATPase and a diminution of mitochondrial calcium accumulation. Pre-treatment with THC significantly mitigated the toxic effects of As in the rat liver as well as scavenged the As-related free radicals [202]. Supporting those findings, long time exposure to NaAso2 resulted in increased in the levels of AST, ALT, ALP and lactate dehydrogenase (LDH), decreased activities of membrane-bound ATPases, enzymatic antioxidants including SOD, Cat, GPx, GST, GR and G6PD along with non-enzymatic antioxidants like reduced GSH, total SH-groups, vitamins C and E. Administration of THC showed a significant inhibition of As-induced hepatotoxicity [203]. Accumulating evidence shows that As can trigger ROS such as singlet oxygen, superoxide anion, hydrogen peroxide, hydroxyl radical, and peroxyl radicals [204].

The HER-2 gene is a putative oncoprotein which is up-regulated in many types of human tumors. Interestingly, it has been reported that As could induce the over-expression of HER-2 and other oncoproteins; and CUR, as a chemopreventive and therapeutic agent has the inhibitory activity on HER-2-overexpressed hepatocellular carcinoma. Based on these results, it could be proposed that CUR has the potential to be developed as a complementary anti-cancer agent to treat hepatocellular carcinoma. Besides, CUR can protect hepatic cells from As-toxicity damage [205].

\subsection{Dermal disorders}

iAs exposure increases the susceptibility to different dermal pathologies such as hyperkeratosis and skin tumor. Immunohistochemical evidence indicated that the appearance of 8-oxo-deoxyguanosine(8-oxodG) in keratosis and healthy tissues of As induced skin malignancies [206].

CUR can lead to Nrf2 activation, Nrf2 protein nuclear accumulation and over-expression of ARE-target genes in the HaCaT keratinocytes. CUR at high doses also enhanced the 
translation of the Nrf2. Administration of low doses of CUR increased the viability of HaCaT cells from the iAs-intoxication and also mitigated the Asi-induced transcription of cleaved caspase-3 and PARP. On the other hand, the expression of Nrf2 is under the control of Kelch-like ECH-associated protein 1 (KEAP1) via ubiquitination and proteasomal degradation. Interestingly, the transcription of $K E A P 1$ was also increased by CUR, indicating possible feedback from Nrf2 to KEAP1. Notably, KEAP1 knockdown remarkably weakened the cytoprotection of CUR [126]. It may be since NRF2 was already fully activated owning to the absence of $K E A P 1$, and thus maximum protection against iAs was already in place, as pointed via the significant right-ward shift of the response curve observed in the untreated cells. Thus, CUR treatment did not further activate NRF2 and hence, no further protection [126].

\subsection{Other arsenic induced-pathologic conditions}

Chorionic exposure to As disturbs the action of several cellular immune components including leukocytes and macrophages thereby affects cellular immune responses resulting in immunosuppression [84, 207]. Different mechanisms for the effect of As on the immunity have been proposed. Apoptosis has been found as an major mechanism of As-induced immunosuppression in human [208]. A study on peripheral blood mononuclear cells of cases which drinking water with low/moderate As levels revealed modulations in expression of $\mathrm{T}$ cell receptor (TCR), T cell cycle regulation, and apoptosis [209]. Anemia and leucopenia are among the most common effects of toxicity from acute or chronic As exposure. It has been reported that the Haridra (turmeric root) attenuates the experimentally As-induced reduction of hemoglobin level, red blood cell count and white blood cell count in calves [210]. CUR can reverse the haematological alterations through restoration of enzymes related to haem biosynthesis, elevating feed intake and promoting the excretion of As via urine and faeces $[210]$. 
It has been shown that CUR can protect against immune dysfunction due to the As exposure. Considering spleen weight as an indicator of splenic dysfunction, As reduced the splenic lymphocyte proliferation, delayed-type hypersensitivity response and secondary antibody response to a specific antigen which was reversed by CUR [129]. CUR has a protective effect against As-related apoptosis in the rat thymocytes through its free radical scavenging potential [211].

An excess of ROS can be implicated in several reproductive disorders such as polycystic ovary syndrome. Wang and colleagues established an animal model of the ovarian OS by injection of $\mathrm{NaAsO} 2$ to examine the inhibitory role of CUR against OS damage. CUR therapy significantly elevates SOD, whereas reducing the ROS and MDA in the ovary. Immunohistochemistry of the ovarian tissues demonstrated that the higher value of atretic follicles and the suppression of granular cells proliferation under OS would be abrogated via CUR treatment. In addition, the OS-induced p66Shc over-expression would be mitigated after CUR therapy. Altogether, these findings demonstrate that CUR can scavenge free radicals and provide the antioxidant circumstances in ovarian tissue upon modulating the expression of p66Shc [212]. $\mathrm{NaAsO} 2$ inhibited the actions of the uterine enzymatic antioxidants including SOD, Cat, and peroxidase. The circulating levels of vitamin B12 and folic acid were reduced followed by an elevated serum LDH, homocysteine level and hepatic metallothionein-1 in As-treated rats. Uterine tissue necrosis with the disturbance of ovarian steroidogenesis was manifested in As-administrated rats with an over-expression of uterine NF- $\kappa \mathrm{B}$ and IL-6 as well as an increase in serum TNF- $\alpha$ levels. Oral supplementation of CUR (20 mg/kg BW/day) in As-treated rats reversed these abnormalities by detoxifying As. The underlying mechanism of As detoxification might be implicated in the stabilization of the S-adenosine methionine (SAM) pool by maintaining the circulating levels of vitamin B12, folate, and homocysteine [213]. 
$\mathrm{NaAsO} 2$ directly affects the antioxidant enzymes (SOD, Cat, GPx, and GST) and regulation of antioxidant genes (SOD1, Cat, and GPx1) in embryonic fibroblast cells and caused oxidative damage through increasing the cellular levels of hydrogen peroxide, hydroxyl radical and LPO. It has been found that CUR potentially improved antioxidant system genes and enzymes to defend the fibroblast cell toxicity created by NaAsO2 [214].

\section{Conclusion and future prospective}

The gold standard treatment of As poisoning is by 'chelation therapy' though chelating drugs are limited by different side effects and reduced selectivity and specificity. Accumulating evidence supports that CUR administration is effective in combating As-mediated toxicity in Wistar rats and Swiss albino rats. However, most of the studies discussed does not demonstrate the capability of CUR in reducing the body burden of As nor any efficacy in humans with chronic arsenic poisoning. In addition, no placebo-controlled trials with this natural agent have been performed nor the efficacy of their long-term use has been assessed. The benefits of CUR at the cellular level should be validated in human subjects with chronic As toxicity. The beneficial effects of CUR should be assessed in arsenecosis through endpoint evaluations such as changes in the As concentrations in blood, nail and faeces, changes in urine As metabolites, size of keratotic lesion or scoring of palmar arsenical keratosis. Suggested markers for evaluation of the effect of CUR in As-associated kidney damage among arsenicosis patients are expression levels of kidney injury molecule (KIM) and changes in the activities of enzymes-related with carbohydrate metabolism such as hexokinase, LDH, G6PD and malate dehydrogenase. Additionally, It was observed that As disrupts the normal levels of metabolic enzymes in the body which are robust biomarkers of toxicity, and could be used as screening markers for As-induced tissue damage in human beings. 
It has been suggested that co-treatment with CUR and arsenate chelator may offer advantageous effects in a synergistic manner on the adverse alterations in the oxidative stress induced by As. The development of novel pharmaceutical delivery approaches of CUR may have higher efficacy compared to its conventional administration. CUR intervention may be a promising approach for the prevention of As-induced damage and should be tested in clinical studies. Therefore, CUR, a spice once associated with the kitchen shelf, will be promoted to the clinic and may accept to be "Curecumin"[215]. 


\section{Figures legends:}

Figure 1. Structure of arsenic compounds.

Figure 2. Toxicity of Arsenic in different organs. Abbreviations: micronucleus (MN), 8-hydroxy-20deoxyguanosine (8-OHdG), p38 mitogen-activated protein kinase(MAPK), reactive oxygen species (ROS), oxidative stress (OS)

Figure 3. Molecular mechanism of arsenic toxicity in different organs. Abbreviations: heme oxygenase 1 (HO-1), activation of activator protein-1 (AP-1), reactive oxygen species (ROS).

Figure 4. Ameliorative effects of curcumin against arsenic-induced toxicity. Arsenic exposure leads to ROS generation which results in oxidative stress and deactivation of the cellular signaling pathway, and ultimately DNA damage, apoptosis and organ dysfunction. Curcumin reverses the arsenic-induced ROS generation and activates the antioxidant enzyme. Abbreviations: NAD(P)H:quinone oxidoreductase 1 (NQO1), GSTs, Gama-glutamylcysteine synthetase heavy subunit ( $\gamma$-GCSh) and light subunit, heme oxygenase 1 (HO-1), nuclear factor (erythroid-2 related) factor 2(Nrf2), superoxide dismutase (SOD), catalase (Cat), glutathione peroxidase (GPx), glutathione reductase (GR), glutathione-S-transferase (GST), and glucose-6-phosphate dehydrogenase (G6PD), reactive oxygen species (ROS), c-Jun amino-terminal kinase (JNK). 


\begin{tabular}{|c|c|c|c|}
\hline Arm & Experimental model & Consequence & Ref. \\
\hline \multicolumn{4}{|l|}{ Neurotoxicity } \\
\hline $\begin{array}{l}\mathrm{NaAsO} 2(20 \mathrm{mg} / \mathrm{kg} \mathrm{BW} ; 28 \\
\text { days }+ \text { CUR (100 mg/kg BW; } \\
28 \text { days })\end{array}$ & -female Wistar rats & $\begin{array}{l}\text {-increase in the activity of GPx, SOD, GSH and } \\
\text { decrease of MDA in frontal cortex, corpus striatum } \\
\text { and hippocampus } \\
\text {-increase of binding of striatal dopamine receptors } \\
\text { and tyrosine hydroxylase expression } \\
\end{array}$ & {$[163]$} \\
\hline $\begin{array}{l}\mathrm{NaAsO} 2(20 \mathrm{mg} / \mathrm{kg} \mathrm{BW} ; 28 \\
\text { days })+\mathrm{CUR}(100 \mathrm{mg} / \mathrm{kg} \mathrm{BW} ; \\
28 \text { days })\end{array}$ & -female Wistar rats & $\begin{array}{l}\text {-elevated levels of catecholamines and their } \\
\text { metabolites as well as serotonin } \\
\text {-reduced levels of NO in brain regions } \\
\end{array}$ & {$[128]$} \\
\hline $\begin{array}{l}\mathrm{NaAsO} 2(2 \mathrm{mg} / \mathrm{kg}) \text { and ECNPs } \\
(1.5 \text { or } 15 \mathrm{mg} / \mathrm{kg})\end{array}$ & $\begin{array}{l}\text {-male Wistar } \\
\text { rats } \\
\end{array}$ & $\begin{array}{l}\text {-ameliorated alterations in hepatic OS markers and } \\
\text { restoration of blood GSH }\end{array}$ & {$[196]$} \\
\hline $\begin{array}{l}\mathrm{NaAsO} 2(20 \mathrm{mg} / \mathrm{kg} \mathrm{BW})+\mathrm{CUR} \\
(100 \mathrm{mg} / \mathrm{kg} \mathrm{BW})\end{array}$ & -female Wistar rats & $\begin{array}{l}\text {-increased learning and memory execution related } \\
\text { to over binding of [3H]-QNB and activity of } \mathrm{AChE} \\
\text { in hippocampus and frontal cortex } \\
\text {-elevation of choline acetyltransferase and binding } \\
\text { of cholinergic-MAChR, Nissl-stained } \\
\text { hippocampus }\end{array}$ & {$[186]$} \\
\hline $\begin{array}{l}\text { As }(20 \mathrm{mg} / \mathrm{kg} \mathrm{BW})+\mathrm{CUR}(100 \\
\mathrm{mg} / \mathrm{kg} \mathrm{BW}) 28 \text { days }\end{array}$ & $\begin{array}{l}\text {-male rats of Wistar } \\
\text { rat }\end{array}$ & $\begin{array}{l}\text {-defend against alterations in the mitochondrial } \\
\text { membrane integrity, function of mitochondrial } \\
\text { complexes and reduction in the CHRM2 receptor } \\
\text { gene in specific brain regions together with } \\
\text { regulating the amplification of brain pro- and } \\
\text { anti-apoptotic proteins }\end{array}$ & {$[188]$} \\
\hline $\begin{array}{l}\mathrm{NaAsO} 2(20 \mathrm{mg} / \mathrm{kg} \mathrm{BW})+\mathrm{CUR} \\
(100 \mathrm{mg} / \mathrm{kg} \mathrm{BW}) 28 \text { days }\end{array}$ & $\begin{array}{l}\text {-male rats of Wistar } \\
\text { rat }\end{array}$ & $\begin{array}{l}\text {-protection of arsenic-caused changes in the } \\
\text { regulation of DAD } 2 \text { receptors, pPP1 } \alpha, \text { PKA, } \\
\text { pCREB, and pDARPP32 } \\
\text {-modulation in the regulation of pGSK } 3 \beta \text { and } \\
\text { BDNF in corpus striatum }\end{array}$ & {$[179]$} \\
\hline \multicolumn{4}{|l|}{ Genotoxic effects } \\
\hline $\begin{array}{l}\mathrm{NaAsO} 2(1.4 \mu \mathrm{M})+\mathrm{CUR}(1.7 \\
\mu \mathrm{M}),\end{array}$ & $\begin{array}{l}\text {-peripheral blood } \\
\text { lymphocytes }\end{array}$ & $\begin{array}{l}\text {-decreasing the number of structural aberrations, } \\
\text { and hypoploidy }\end{array}$ & {$[154]$} \\
\hline $\begin{array}{l}\text { CUR (500 mg twice daily for } 3 \\
\text { month) }\end{array}$ & $\begin{array}{l}\text {-peripheral blood } \\
\text { lymphocytes }\end{array}$ & $\begin{array}{l}\text {-combating ROS production and lipid peroxidation } \\
\text {-promotion the activities of numerous antioxidant } \\
\text { enzymes i.e. Cat, SOD, GPx, GR, GST and GSH }\end{array}$ & {$[122]$} \\
\hline $\begin{array}{l}\text { CUR (500 mg twice daily } 3 \\
\text { months) }\end{array}$ & $\begin{array}{l}\text {-peripheral blood } \\
\text { lymphocytes }\end{array}$ & $\begin{array}{l}\text { - suppression of the 8-OHdG value and OGG1 } \\
\text { regulation } \\
\text {-activation of DNA repair enzymes participated in } \\
\text { the repair pathways at protein and genetic levels } \\
\end{array}$ & {$[155]$} \\
\hline $\begin{array}{l}\text { NaAsO2 (25 ppm)+CUR-NP } \\
(100 \mathrm{mg} / \mathrm{kg} \mathrm{BW})\end{array}$ & -rat & $\begin{array}{l}\text {-attenuated chromosomal aberrations, micronuclei } \\
\text { formation, DNA damage }\end{array}$ & {$[156]$} \\
\hline $\begin{array}{l}\mathrm{NaAsO} 2(500 \mu \mathrm{g} / \mathrm{l})+\mathrm{CUR}(5,10 \\
\text { and } 15 \mathrm{mg} / \mathrm{kg} \mathrm{BW} / \text { daily })\end{array}$ & $\begin{array}{l}\text {-Normal male Swiss } \\
\text { albino }\end{array}$ & $\begin{array}{l}\text {-prevented NaAsO2-induced DNA lesions through } \\
\text { decreasing comet tail moment of whole blood and } \\
\text { MN population in cultured spleenic lymphocytes }\end{array}$ & {$[160]$} \\
\hline $\begin{array}{l}\text { As2O3 }(0.1,0.2,0.5,1,2.5, \text { and } \\
5 \mathrm{mg} / 1)+\mathrm{CUR}(1,2,5,10,20, \\
\text { and } 50 \mu \mathrm{M})\end{array}$ & -neural precursor cells & $\begin{array}{l}\text {-promoted telomerase activity of neural } \\
\text { stem/progenitor cells } \\
\text {-decreased arsenic-created apoptosis (by } \\
\text { inactivation of caspases) and-ROS generation } \\
\end{array}$ & {$[176]$} \\
\hline $\begin{array}{l}\mathrm{NaAsO} 2(100,250,500 \text { and } \\
1000 \mu \mathrm{M})+\mathrm{CUR}(10,25 \text { and } 50 \\
\mu \mathrm{M})\end{array}$ & $\begin{array}{l}\text {-peripheral blood } \\
\text { lymphocytes }\end{array}$ & $\begin{array}{l}\text {-reduction in comet tail moment } \\
\text {-quenching the OS } \\
\text {-regression in DNA damage }\end{array}$ & {$[161]$} \\
\hline
\end{tabular}




\begin{tabular}{|c|c|c|c|}
\hline $\begin{array}{l}\text { As2O3 (4 mg/kg BW; 45 } \\
\text { days+CUR(15 mg/kg BW) }\end{array}$ & -male Wistar rats & $\begin{array}{l}\text {-decrement in hepatic arsenic accumulation and } \\
\text { serum marker enzymes including AST, ALT and } \\
\text { ALP }\end{array}$ & [195] \\
\hline As+ CUR & $\begin{array}{l}\text {-female Kunming } \\
\text { mice }\end{array}$ & $\begin{array}{l}\text {-enhance arsenic methylation and urinary excretion } \\
\text {-overexpression of hepatic Nrf2 protein and its } \\
\text { downstream genes (NQO1 and HO-1) }\end{array}$ & [125] \\
\hline $\begin{array}{l}\text { As2O3(0.4 mg/kg BW) } \\
+ \text { CUR(0.4 mg/kg BW) }\end{array}$ & $\begin{array}{l}\text {-adult male Swiss } \\
\text { Albino Mic }\end{array}$ & $\begin{array}{l}\text { - decreased intracellular ROS generation via } \\
\text { promoting the activity of GSH generating enzyme } \\
\text { GR and ROS scavenging enzymes (GST, GPx, } \\
\text { SOD and Cat) in hepatic tissue }\end{array}$ & [127] \\
\hline $\begin{array}{l}\text { CUR-NP }(100 \mathrm{mg} / \mathrm{kg} \\
\text { BW) }\end{array}$ & -male Wistar rats & $\begin{array}{l}\text {-decreased LPO } \\
\text {-increased the activities of SOD, Cat, GPx and GR } \\
\text { in liver }\end{array}$ & [197] \\
\hline $\begin{array}{l}\mathrm{NaAsO} 2(5 \mu \mathrm{M})+\mathrm{CUR}(5 \text { and } \\
10 \mu \mathrm{g} / \mathrm{ml})\end{array}$ & -albino Swiss mice & $\begin{array}{l}\text {-mitigated the effects of arsenic on cell viability, } \\
\text { ROS generation, loss in MTP, and hypodiploid } \\
\text { DNA content }\end{array}$ & [201] \\
\hline $\begin{array}{l}\mathrm{As}(5 \mathrm{mg} / \mathrm{kg} \mathrm{BW})+\mathrm{THC}(80 \\
\mathrm{mg} / \mathrm{kg} \mathrm{BW}) 28 \text { days }\end{array}$ & $\begin{array}{l}\text {-male albino Wistar } \\
\text { rats }\end{array}$ & $\begin{array}{l}\text {-decreased the levels of AST, ALT, ALP and LDH } \\
\text {-increased the activities of membrane bound } \\
\text { ATPases, enzymatic antioxidants including SOD, } \\
\text { Cat, GPx, GST, GR and G6PD along with } \\
\text { non-enzymatic antioxidants like reduced GSH, } \\
\text { total SH-groups, vitamins C and E. }\end{array}$ & [203] \\
\hline $\begin{array}{l}\text { As2O3 }(5 \mathrm{mg} / \mathrm{kg} \mathrm{BW})+\mathrm{THC} \\
(80 \mathrm{mg} / \mathrm{kg} \mathrm{BW})\end{array}$ & $\begin{array}{l}\text {-adult male albino } \\
\text { Wistar rats } \\
\end{array}$ & -decreased values of AST, ALT, ALP and bilirubin & [202] \\
\hline \multicolumn{4}{|l|}{ Oxidative damage } \\
\hline $\begin{array}{l}\text { As2O3 }(5 \mathrm{mg} / \mathrm{kg} \mathrm{BW})+\mathrm{CUR} \\
(15 \mathrm{mg} / \mathrm{kg} \mathrm{BW})\end{array}$ & $\begin{array}{l}\text { - male } \\
\text { Sprague-Dawley rats }\end{array}$ & $\begin{array}{l}\text { - reduced the induction in the levels of TBARS } \\
\text {-induced the reduction in the activities of } \\
\text { antioxidant enzymes and the SH-groups levels }\end{array}$ & [148] \\
\hline $\begin{array}{l}\text { As2O3 (25 ppm)+CUR-NP(100 } \\
\mathrm{mg} / \mathrm{kg})\end{array}$ & -male Wistar rats & $\begin{array}{l}\text {-elevated the GSH level in renal and brain } \\
\text {-enhanced GR function in renal and brain tissues } \\
\text {-reduced the LPO }\end{array}$ & [135] \\
\hline $\begin{array}{l}\text { - As2O3 }(8 \mathrm{mg} / \mathrm{kg})+\mathrm{CUR}(0, \\
100,150, \text { or } 200 \mathrm{mg} / \mathrm{kg})\end{array}$ & $\begin{array}{l}\text {-female Kunming } \\
\text { mouse }\end{array}$ & $\begin{array}{l}\text { - elevate SOD } \\
\text {-decrease ROS and MDA in the ovary } \\
\text {-abrogating both higher value of atretic follicles } \\
\text { and suppression of granular cells proliferation } \\
\text { under OS } \\
\text {-mitigating the OS-induced p66Shc } \\
\text { over-expression }\end{array}$ & [212] \\
\hline \multicolumn{4}{|l|}{ Nephrotoxicity } \\
\hline $\begin{array}{l}\mathrm{NaAsO} 2(5 \mathrm{mg} / \mathrm{kg})+\mathrm{CUR}(100 \\
\mathrm{mg} / \mathrm{kg})\end{array}$ & $\begin{array}{l}\text { - adult male NMRI } \\
\text { mice }\end{array}$ & $\begin{array}{l}\text {-increase the diameter of glomerulus and proximal } \\
\text { tubule, glomerular area, total antioxidant capacity } \\
\text {-decrease serum concentration of MDA }\end{array}$ & [134] \\
\hline $\begin{array}{l}\text { As2O3+Curcuma } \\
\text { aromatic }(50 \mathrm{mg} / \mathrm{kg} \mathrm{BW})\end{array}$ & $\begin{array}{l}\text { - male Wistar albino } \\
\text { rats }\end{array}$ & $\begin{array}{l}\text {-increament of the serum level of uric acid, } \\
\text { blood urea nitrogen, and creatinine because of } \\
\text { renal dysfunction } \\
\text {-normalization of the serum levels of uric acid, } \\
\text { blood urea nitrogen and creatinine }\end{array}$ & [137] \\
\hline $\begin{array}{l}\mathrm{As} 2 \mathrm{O} 3(5 \mathrm{mg} / \mathrm{kg} \mathrm{BW})+\mathrm{CUR}(15 \\
\mathrm{mg} / \mathrm{kg} \mathrm{BW})\end{array}$ & -male Wistar rats & $\begin{array}{l}\text {-mitigates the elevation of liver function enzymes, } \\
\text { lipid and protein profile, and } \\
\text { indices of renal injury }\end{array}$ & {$[46]$} \\
\hline
\end{tabular}




\begin{tabular}{|c|c|c|c|}
\hline $\mathrm{iAs}(30 \mu \mathrm{M})+\mathrm{CUR}(20 \mu \mathrm{M})$ & $\begin{array}{l}\text {-human keratinocytes } \\
\text { (HaCaT cells) }\end{array}$ & $\begin{array}{l}\text {-elevated the viability of } \mathrm{HaCaT} \text { cells } \\
\text {-mitigated Asi-induced transcription of cleaved } \\
\text { caspase-3 and PARP }\end{array}$ & {$[126]$} \\
\hline \multicolumn{4}{|l|}{ Other pathologies } \\
\hline $\begin{array}{l}\text { As }(20 \mathrm{ppm})+\mathrm{CUR}(100 \mathrm{mg} / \mathrm{kg} \\
\text { BW) }\end{array}$ & $\begin{array}{l}\text {-adult male Wistar } \\
\text { rats }\end{array}$ & $\begin{array}{l}\text { - inhibit arsenic-related apoptosis in rat thymocytes } \\
\text { by its free radical scavenging }\end{array}$ & {$[211]$} \\
\hline $\begin{array}{l}\text { CUR-NP }(100 \mathrm{mg} / \mathrm{kg} \mathrm{BW})+ \\
\text { As2O3 }(25 \mathrm{ppm})\end{array}$ & -male Wistar rats & $\begin{array}{l}\text {-decreased the spleen weight } \\
\text {-increased the splenic lymphocyte proliferation } \\
\text { - induced type hypersensitivity response and } \\
\text { secondary antibody response to specific antigen }\end{array}$ & {$[129]$} \\
\hline \multicolumn{4}{|c|}{$\begin{array}{l}\text { Abbreviations: alanine transaminase (ALT), alkaline phosphatase (ALP), arsenic (As), aspartate transaminase (AST), body } \\
\text { weight (BW), catalase (Cat), curcumin (CUR), encapsulated curcumin nanoparticles (ECNPs), glucose-6-phosphate } \\
\text { dehydrogenase (G6PD), glutathione (GSH), glutathione peroxidase (GPx), glutathione reductase (GR), } \\
\text { glutathione-S-transferase (GST), heme oxygenase-1 (HO-1), inorganic arsenic (iAs), lactate dehydrogenase } \\
\text { (LDH),lipid peroxidation (LPO), Malondialdehyde (MDA), Micronucleus (MN), mitochondrial transmembrane potential } \\
\text { (MTP), muscarinic receptors (MAChR), NADP(H) quinine oxidoreductase 1 (NQO1), nanoparticles encapsulated curcumin } \\
\text { (CUR-NP), oxidative stress (OS), sulfhydryl groups (SH-groups), superoxide dismutase (SOD), tetrahydrocurcumin } \\
\text { (THC), thiobarbituric acid-reactive substances (TBARS), [3H]quinuclidinyl benzylate ([3H]-QNB), } \\
\text { 8-hydroxy-2'-deoxyguanosine (8-OHdG). }\end{array}$} \\
\hline
\end{tabular}




\section{References:}

[1] T. Stummann, L. Hareng, S. Bremer, Embryotoxicity hazard assessment of cadmium and arsenic compounds using embryonic stem cells, Toxicology, 252 (2008) 118-122.

[2] D.G. Mazumder, Chronic arsenic toxicity \& human health, Indian J Med Res, 128 (2008) 436-447.

[3] B.K. Mandal, K.T. Suzuki, Arsenic round the world: a review, Talanta, 58 (2002) 201-235.

[4] A.K. Das, R. Sahu, T.K. Dua, S. Bag, M. Gangopadhyay, M.K. Sinha, S. Dewanjee, Arsenic-induced myocardial injury: protective role of Corchorus olitorius leaves, Food and chemical toxicology, 48 (2010) 1210-1217.

[5] R. Rodriguez, N. Basta, S. Casteel, F. Armstrong, D. Ward, Chemical extraction methods to assess bioavailable arsenic in soil and solid media, Journal of Environmental Quality, 32 (2003) 876-884.

[6] K. Ramanathan, S. Shila, S. Kumaran, C. Panneerselvam, Protective role of ascorbic acid and a-tocopherol on arsenic-induced microsomal dysfunctions, Human \& experimental toxicology, 22 (2003) 129-136.

[7] M.F. Naujokas, B. Anderson, H. Ahsan, H.V. Aposhian, J.H. Graziano, C. Thompson, W.A. Suk, The broad scope of health effects from chronic arsenic exposure: update on a worldwide public health problem, Environmental health perspectives, 121 (2013) 295-302.

[8] S. Shila, M. Subathra, M.A. Devi, C. Panneerselvam, Arsenic intoxication-induced reduction of glutathione level and of the activity of related enzymes in rat brain regions: reversal by dl- $\alpha$-lipoic acid, Archives of toxicology, 79 (2005) 140-146.

[9] H.V. Aposhian, M.M. Aposhian, Newer developments in arsenic toxicity, Journal of the American College of Toxicology, 8 (1989) 1297-1305.

[10] H.V. APOSHIAN, Biochemical toxicology of arsenic, Rev Biochem Toxicol, 10 (1989) 265-299.

[11] O.P. Dhankher, Arsenic metabolism in plants: an inside story, The New phytologist, 168 (2005) 503-505.

[12] A. Sattar, S. Xie, M.A. Hafeez, X. Wang, H.I. Hussain, Z. Iqbal, Y. Pan, M. Iqbal, M.A. Shabbir, Z. Yuan, Metabolism and toxicity of arsenicals in mammals, Environmental toxicology and pharmacology, 48 (2016) 214-224.

[13] C. Kumana, W. Au, N. Lee, M. Kou, R. Mak, C. Lam, Y. Kwong, Systemic availability of arsenic from oral arsenic-trioxide used to treat patients with hematological malignancies, European journal of clinical pharmacology, 58 (2002) 521-526.

[14] J.-P. Buchet, R. Lauwerys, H. Roels, Urinary excretion of inorganic arsenic and its metabolites after repeated ingestion of sodium metaarsenite by volunteers, International archives of occupational and environmental health, 48 (1981) 111-118.

[15] S.J. Flora, Arsenic-induced oxidative stress and its reversibility, Free Radical Biology and Medicine, 51 (2011) 257-281.

[16] S. Flora, A. Mehta, Monoisoamyl dimercaptosuccinic acid abrogates arsenic-induced developmental toxicity in human embryonic stem cell-derived embryoid bodies: comparison with in vivo studies, Biochemical pharmacology, 78 (2009) 1340-1349.

[17] S.M. Cohen, A. Chowdhury, L.L. Arnold, Inorganic arsenic: A non-genotoxic carcinogen, Journal of Environmental Sciences, 49 (2016) 28-37.

[18] K.T. Kitchin, K. Wallace, The role of protein binding of trivalent arsenicals in arsenic carcinogenesis and toxicity, Journal of inorganic biochemistry, 102 (2008) 532-539.

[19] J.S. Woods, B.A. Fowler, Altered regulation of mammalian hepatic heme biosynthesis and urinary porphyrin excretion during prolonged exposure to sodium arsenate, Toxicology and applied pharmacology, 43 (1978) 361-371.

[20] K. Jomova, Z. Jenisova, M. Feszterova, S. Baros, J. Liska, D. Hudecova, C. Rhodes, M. Valko, Arsenic: toxicity, oxidative stress and human disease, Journal of Applied Toxicology, 31 (2011) 95-107.

[21] S. Bhattacharya, P.K. Haldar, Trichosanthes dioica root alleviates arsenic induced myocardial toxicity in rats, Journal of Environmental Pathology, Toxicology and Oncology, 32 (2013). 
[22] N. Parsamanesh, M. Moossavi, A. Bahrami, A.E. Butler, A. Sahebkar, Therapeutic potential of curcumin in diabetic complications, Pharmacological research, (2018).

[23] A. Bahrami, S.L. Atkin, M. Majeed, A. Sahebkar, Effects of curcumin on hypoxia-inducible factor as a new therapeutic target, Pharmacological research, (2018).

[24] M.F. Hughes, B.D. Beck, Y. Chen, A.S. Lewis, D.J. Thomas, Arsenic exposure and toxicology: a historical perspective, Toxicological Sciences, 123 (2011) 305-332.

[25] F. Chen, X. Shi, Intracellular signal transduction of cells in response to carcinogenic metals, Critical reviews in oncology/hematology, 42 (2002) 105-121.

[26] K. Hossain, A.A. Akhand, M. Kato, J. Du, K. Takeda, J. Wu, K. Takeuchi, W. Liu, H. Suzuki, I. Nakashima, Arsenite induces apoptosis of murine $T$ lymphocytes through membrane raft-linked signaling for activation of c-Jun amino-terminal kinase, The Journal of Immunology, 165 (2000) 4290-4297.

[27] W. Park, J. Seol, kim ES, Hyun JM, Jung CW, Lee CC, kim Bk and Lee yy: Arsenic trioxide-mediated growth inhibition in MC/CAR myeloma cells via cell cycle arrest in association with induction of cyclin-dependent kinase inhibitor, p21, and apoptosis, Cancer Res, 60 (2000) 3065-3071.

[28] W.H. Park, Y.H. Cho, C.W. Jung, J.O. Park, K. Kim, Y.H. Im, M.H. Lee, W.K. Kang, K. Park, Arsenic trioxide inhibits the growth of A498 renal cell carcinoma cells via cell cycle arrest or apoptosis, Biochemical and biophysical research communications, 300 (2003) 230-235.

[29] L.-H. Yih, T.-C. Lee, Arsenite induces p53 accumulation through an ATM-dependent pathway in human fibroblasts, Cancer Research, 60 (2000) 6346-6352.

[30] P. Kapahi, T. Takahashi, G. Natoli, S.R. Adams, Y. Chen, R.Y. Tsien, M. Karin, Inhibition of NF- $\kappa$ B activation by arsenite through reaction with a critical cysteine in the activation loop of $\mathrm{I} \kappa \mathrm{B}$ kinase, Journal of Biological Chemistry, 275 (2000) 36062-36066.

[31] Y. Kumagai, D. Sumi, Arsenic: signal transduction, transcription factor, and biotransformation involved in cellular response and toxicity, Annu. Rev. Pharmacol. Toxicol., 47 (2007) 243-262.

[32] Z. Tan, T. Kang, X. Zhang, Y. Tong, S. Chen, Nerve growth factor prevents arsenic-induced toxicity in PC12 cells through the AKT/GSK-3 $\beta$ /NFAT pathway, Journal of cellular physiology, 234 (2019) 4726-4738.

[33] G.L. Johnson, R. Lapadat, Mitogen-activated protein kinase pathways mediated by ERK, JNK, and p38 protein kinases, Science, 298 (2002) 1911-1912.

[34] M. Humar, T. Loop, R. Schmidt, A. Hoetzel, M. Roesslein, N. Andriopoulos, H.L. Pahl, K.K. Geiger, B.H. Pannen, The mitogen-activated protein kinase p38 regulates activator protein 1 by direct phosphorylation of c-Jun, The international journal of biochemistry \& cell biology, 39 (2007) 2278-2288.

[35] J. Ventura-Lima, M.R. Bogo, J.M. Monserrat, Arsenic toxicity in mammals and aquatic animals: a comparative biochemical approach, Ecotoxicology and environmental safety, 74 (2011) 211-218.

[36] C. Huang, A.M. Bode, N.-Y. Chen, W.-Y. Ma, J. Li, M. Nomura, Z. Dong, Transactivation of AP-1 in AP-1-luciferase reporter transgenic mice by arsenite and arsenate, Anticancer research, 21 (2001) 261-267.

[37] C. Huang, J. Li, M. Ding, L. Wang, X. Shi, V. Castranova, V. Vallyathan, G. Ju, M. Costa, Arsenic-induced NF $\kappa \beta$ transactivation through Erks-and JNKs-dependent pathways in mouse epidermal JB6 cells, Molecular and cellular biochemistry, 222 (2001) 29-34.

[38] C.R. Tyler, A.M. Allan, The effects of arsenic exposure on neurological and cognitive dysfunction in human and rodent studies: a review, Current environmental health reports, 1 (2014) 132-147.

[39] M.A. Lemmon, J. Schlessinger, Cell signaling by receptor tyrosine kinases, Cell, 141 (2010) 1117-1134.

[40] W. Wu, L.M. Graves, I. Jaspers, R.B. Devlin, W. Reed, J.M. Samet, Activation of the EGF receptor signaling pathway in human airway epithelial cells exposed to metals, American Journal of Physiology-Lung Cellular and Molecular Physiology, 277 (1999) L924-L931.

[41] I. Suc, O. Meilhac, I. Lajoie-mazenc, J. Vandaele, G.n. Jürgens, R. Salvayre, A. Nègre-salvayre, Activation of EGF receptor by oxidized LDL, The FASEB Journal, 12 (1998) 665-671. 
[42] K.J. Herbert, E.T. Snow, Modulation of arsenic-induced epidermal growth factor receptor pathway signalling by resveratrol, Chemico-biological interactions, 198 (2012) 38-48.

[43] T. Tanaka-Kagawa, N. Hanioka, H. Yoshida, H. Jinno, M. Ando, Arsenite and arsenate activate extracellular signal-regulated kinases $1 / 2$ by an epidermal growth factor receptor-mediated pathway in normal human keratinocytes, British Journal of Dermatology, 149 (2003) 1116-1127.

[44] J. Li, M. Gorospe, J. Barnes, Y. Liu, Tumor promoter arsenite stimulates histone H3 phosphoacetylation of proto-oncogenes c-fos and c-jun chromatin in human diploid fibroblasts, Journal of Biological Chemistry, 278 (2003) 13183-13191.

[45] V.K. Gupta, A. Kumar, S.H. Yadav, R. Pandey, B. Sharma, Acetylcholinesterase as a Biomarker of Arsenic Induced Cardiotoxicity in Mammals, Science International, 5 (2017) 142-149.

[46] M.I. Yousef, F.M. El-Demerdash, F.M. Radwan, Sodium arsenite induced biochemical perturbations in rats: ameliorating effect of curcumin, Food and Chemical Toxicology, 46 (2008) 3506-3511.

[47] N.-Y. Chen, W.-Y. Ma, C. Huang, M. Ding, Z. Dong, Activation of PKC is required for arsenite-induced signal transduction, Journal of environmental pathology, toxicology and oncology: official organ of the International Society for Environmental Toxicology and Cancer, 19 (2000) 297-305.

[48] G.P. Kaushal, S.V. Shah, Autophagy in acute kidney injury, Kidney international, 89 (2016) 779-791.

[49] I. Dikic, Z. Elazar, Mechanism and medical implications of mammalian autophagy, Nature reviews Molecular cell biology, 19 (2018) 349.

[50] A. Kimura, Y. Ishida, M. Nosaka, Y. Kuninaka, M. Hama, T. Kawaguchi, S. Sakamoto, K. Shinozaki, Y. Iwahashi, T. Takayasu, Exaggerated arsenic nephrotoxicity in female mice through estrogen-dependent impairments in the autophagic flux, Toxicology, 339 (2016) 9-18.

[51] S. Higuchi, H. Ohtsu, H. Suzuki, H. Shirai, G.D. Frank, S. Eguchi, Angiotensin II signal transduction through the AT1 receptor: novel insights into mechanisms and pathophysiology, Clinical science, 112 (2007) 417-428.

[52] C. Savoia, D. Burger, N. Nishigaki, A. Montezano, R.M. Touyz, Angiotensin II and the vascular phenotype in hypertension, Expert reviews in molecular medicine, 13 (2011).

[53] E. Hossain, A. Ota, M. Takahashi, S. Karnan, L. Damdindorj, Y. Konishi, H. Konishi, Y. Hosokawa, Arsenic upregulates the expression of angiotensin II Type I receptor in mouse aortic endothelial cells, Toxicology letters, 220 (2013) 70-75.

[54] J.E. Bodwell, L.A. Kingsley, J.W. Hamilton, Arsenic at Very Low Concentrations Alters Glucocorticoid Receptor (GR)-Mediated Gene Activation but Not GR-Mediated Gene Repression: Complex Dose- Response Effects Are Closely Correlated with Levels of Activated GR and Require a Functional GR DNA Binding Domain, Chemical research in toxicology, 17 (2004) 1064-1076.

[55] R.H. Oakley, J.A. Cidlowski, The biology of the glucocorticoid receptor: new signaling mechanisms in health and disease, Journal of Allergy and Clinical Immunology, 132 (2013) 1033-1044.

[56] R.C. Kaltreider, A.M. Davis, J.P. Lariviere, J.W. Hamilton, Arsenic alters the function of the glucocorticoid receptor as a transcription factor, Environmental health perspectives, 109 (2001) 245-251.

[57] A.E. Rosenblatt, K.L. Burnstein, Inhibition of androgen receptor transcriptional activity as a novel mechanism of action of arsenic, Molecular Endocrinology, 23 (2009) 412-421.

[58] J.C. Davey, J.E. Bodwell, J.A. Gosse, J.W. Hamilton, Arsenic as an endocrine disruptor: effects of arsenic on estrogen receptor-mediated gene expression in vivo and in cell culture, Toxicological sciences, 98 (2007) 75-86.

[59] E.J. Martinez, B.L. Kolb, A. Bell, D.D. Savage, A.M. Allan, Moderate perinatal arsenic exposure alters neuroendocrine markers associated with depression and increases depressive-like behaviors in adult mouse offspring, Neurotoxicology, 29 (2008) 647-655. 
[60] J. Davey, A. Nomikos, M. Wungjiranirun, Sher-man JR, Ingram L, Batki C, Lariviere JP, Hamilton JW. Arsenic as an endocrine disruptor: arsenic disrupts retino-ic acid receptor-and thyroid hormonereceptor-mediatedgene regulation and thyroid hormone-mediated amphibiantail metamorphosis, Environ Health Perspect, 116 (2008) 165-172.

[61] J.M. Simard, S.K. Woo, V. Gerzanich, Transient receptor potential melastatin 4 and cell death, Pflügers Archiv-European Journal of Physiology, 464 (2012) 573-582.

[62] A. Becerra, C. Echeverría, D. Varela, D. Sarmiento, R. Armisén, F. Nuñez-Villena, M. Montecinos, F. Simon, Transient receptor potential melastatin 4 inhibition prevents lipopolysaccharide-induced endothelial cell death, Cardiovascular research, 91 (2011) 677-684.

[63] C.-X. Yu, Y.-Y. Zhang, X.-Y. Wu, H.-X. Tang, X.-Q. Liang, Z.-M. Xue, Y.-D. Xue, J. Li, H. Zhu, R. Huo, Transient receptor potential melastatin 4 contributes to early-stage endothelial injury induced by arsenic trioxide, Toxicology letters, 312 (2019) 98-108.

[64] H.B. Dixon, E.K. Mutenda, M.J. Sparkes, Enzyme-catalysed Transformations of Compounds Containing the-CH2-AsO3H2 Group, Applied Organometallic Chemistry, 11 (1997) 251-255.

[65] M. Gresser, ADP-arsenate. Formation by submitochondrial particles under phosphorylating conditions, Journal of Biological Chemistry, 256 (1981) 5981-5983.

[66] M.F. Hughes, Arsenic toxicity and potential mechanisms of action, Toxicology letters, 133 (2002) $1-16$.

[67] R. Lagunas, Sugar-arsenate esters: thermodynamics and biochemical behavior, Archives of biochemistry and biophysics, 205 (1980) 67-75.

[68] M. Garcia-Sevillano, M. Contreras-Acuna, T. García-Barrera, F. Navarro, J. Gomez-Ariza, Metabolomic study in plasma, liver and kidney of mice exposed to inorganic arsenic based on mass spectrometry, Analytical and bioanalytical chemistry, 406 (2014) 1455-1469.

[69] S.-J. Jiang, T.-M. Lin, H.-L. Wu, H.-S. Han, G.-Y. Shi, Decrease of fibrinolytic activity in human endothelial cells by arsenite, Thrombosis research, 105 (2002) 55-62.

[70] C. Prakash, M. Soni, V. Kumar, Biochemical and molecular alterations following arsenic-induced oxidative stress and mitochondrial dysfunction in rat brain, Biological trace element research, 167 (2015) 121-129.

[71] N. Prasanna, D.N. Krishnan, M. Rasool, Sodium arsenite-induced cardiotoxicity in rats: protective role of p-coumaric acid, a common dietary polyphenol, Toxicology mechanisms and methods, 23 (2013) 255-262.

[72] L.M. Del Razo, B. Quintanilla-Vega, E. Brambila-Colombres, E.S. Calderón-Aranda, M. Manno, A. Albores, Stress proteins induced by arsenic, Toxicology and applied pharmacology, 177 (2001) 132-148.

[73] G. Nardai, B. Sass, J. Eber, G. Orosz, P. Csermely, Reactive cysteines of the 90-kDa heat shock protein, Hsp90, Archives of biochemistry and biophysics, 384 (2000) 59-67.

[74] E. Sikorski, J. McCay, K. White Jr, S. Bradley, A. Munson, Immunotoxicity of the semiconductor gallium arsenide in female B6C3F1 mice, Toxicological Sciences, 13 (1989) 843-858.

[75] H.-R. Guo, S.R. Lipsitz, H. Hu, R.R. Monson, Using ecological data to estimate a regression model for individual data: the association between arsenic in drinking water and incidence of skin cancer, Environmental Research, 79 (1998) 82-93.

[76] L. Institoris, O. Siroki, Û. Û́ndeger, N. Basaran, I. Desi, Immunotoxicological investigation of subacute combined exposure by permethrin and the heavy metals arsenic (III) and mercury (II) in rats, International immunopharmacology, 1 (2001) 925-933.

[77] E. Sikorski, L. Burns, M. Stern, M. Luster, A.E. Munson, Splenic cell targets in gallium arsenide-induced suppression of the primary antibody response, Toxicology and applied pharmacology, 110 (1991) 129-142.

[78] M. Savabieasfahani, R. Lochmiller, D. Rafferty, J. Sinclair, Sensitivity of wild cotton rats (Sigmodon hispidus) to the immunotoxic effects of low-level arsenic exposure, Archives of environmental contamination and toxicology, 34 (1998) 289-296. 
[79] L.-F. Zhou, Y. Zhu, X.-F. Cui, W.-P. Xie, A.-H. Hu, K.-S. Yin, Arsenic trioxide, a potent inhibitor of $\mathrm{NF}-\kappa \mathrm{B}$, abrogates allergen-induced airway hyperresponsiveness and inflammation, Respiratory research, 7 (2006) 146.

[80] M. Pion, R. Stalder, R. Correa, B. Mangeat, G.J. Towers, V. Piguet, Identification of an arsenic-sensitive block to primate lentiviral infection of human dendritic cells, Journal of virology, 81 (2007) 12086-12090.

[81] C.D. Kozul, K.H. Ely, R.I. Enelow, J.W. Hamilton, Low-dose arsenic compromises the immune response to influenza A infection in vivo, Environmental health perspectives, 117 (2009) 1441-1447.

[82] D.N.G. Mazumder, R. Haque, N. Ghosh, B.K. De, A. Santra, D. Chakraborti, A.H. Smith, Arsenic in drinking water and the prevalence of respiratory effects in West Bengal, India, International journal of epidemiology, 29 (2000) 1047-1052.

[83] M. Rahman, M. Faruk, M. Her, J. Kim, S. Kang, S. Jung, Prevalence of brucellosis in ruminants in Bangladesh, Veterinarni Medicina, 56 (2011) 379-385.

[84] R. Raqib, S. Ahmed, R. Sultana, Y. Wagatsuma, D. Mondal, A.W. Hoque, B. Nermell, M. Yunus, S. Roy, L.A. Persson, Effects of in utero arsenic exposure on child immunity and morbidity in rural Bangladesh, Toxicology letters, 185 (2009) 197-202.

[85] F. Binet, S. Chiasson, D. Girard, Arsenic trioxide induces endoplasmic reticulum stress-related events in neutrophils, International immunopharmacology, 10 (2010) 508-512.

[86] S.W. Burchiel, L.A. Mitchell, F.T. Lauer, X. Sun, J.D. McDonald, L.G. Hudson, K.J. Liu, Immunotoxicity and biodistribution analysis of arsenic trioxide in C57BI/6 mice following a 2-week inhalation exposure, Toxicology and applied pharmacology, 241 (2009) 253-259.

[87] A. Lemarie, C. Morzadec, E. Bourdonnay, O. Fardel, L. Vernhet, Human macrophages constitute targets for immunotoxic inorganic arsenic, The Journal of Immunology, 177 (2006) 3019-3027.

[88] M. Sengupta, B. Bishayi, Effect of lead and arsenic on murine macrophage response, Drug and chemical toxicology, 25 (2002) 459-472.

[89] B. Bishayi, M. Sengupta, Intracellular survival of Staphylococcus aureus due to alteration of cellular activity in arsenic and lead intoxicated mature Swiss albino mice, Toxicology, 184 (2003) 31-39.

[90] A. Lemarie, C. Morzadec, D. Mérino, O. Micheau, O. Fardel, L. Vernhet, Arsenic trioxide induces apoptosis of human monocytes during macrophagic differentiation through nuclear factor- $\kappa$ B-related survival pathway down-regulation, Journal of Pharmacology and Experimental Therapeutics, 316 (2006) 304-314.

[91] E. Bourdonnay, C. Morzadec, O. Fardel, L. Vernhet, Redox-sensitive regulation of gene expression in human primary macrophages exposed to inorganic arsenic, Journal of cellular biochemistry, 107 (2009) 537-547.

[92] E. Bourdonnay, C. Morzadec, L. Sparfel, M.-D. Galibert, S. Jouneau, C. Martin-Chouly, O. Fardel, L. Vernhet, Global effects of inorganic arsenic on gene expression profile in human macrophages, Molecular immunology, 46 (2009) 649-656.

[93] J.M. Bomberger, B.A. Coutermarsh, R.L. Barnaby, B.A. Stanton, Arsenic promotes ubiquitinylation and lysosomal degradation of cystic fibrosis transmembrane conductance regulator (CFTR) chloride channels in human airway epithelial cells, Journal of Biological Chemistry, 287 (2012) 17130-17139.

[94] B. Hernandez-Castro, L. Doniz-Padilla, M. Salgado-Bustamante, D. Rocha, M. Ortiz-Perez, M. Jimenez-Capdeville, D. Portales-Perez, A. Quintanar-Stephano, R. Gonzalez-Amaro, Effect of arsenic on regulatory T cells, Journal of clinical immunology, 29 (2009) 461-469.

[95] S. Ahmed, S.M.-e. Khoda, R.S. Rekha, R.M. Gardner, S.S. Ameer, S. Moore, E.-C. Ekström, M. Vahter, R. Raqib, Arsenic-associated oxidative stress, inflammation, and immune disruption in human placenta and cord blood, Environmental health perspectives, 119 (2010) 258-264.

[96] S.F. Farzan, M.R. Karagas, Y. Chen, In utero and early life arsenic exposure in relation to long-term health and disease, Toxicology and applied pharmacology, 272 (2013) 384-390. 
[97] G.A. Soto-Peña, L. Vega, Arsenic interferes with the signaling transduction pathway of $T$ cell receptor activation by increasing basal and induced phosphorylation of Lck and Fyn in spleen cells, Toxicology and applied pharmacology, 230 (2008) 216-226.

[98] I. Robb, Anionic Surfactants: Physical Chemistry of Surfactant Action, by EH Lucassen-Reynders, Marcel Dekker, New York, (1981) 109-142.

[99] S. Yu, W.T. Liao, C.H. Lee, C.Y. Chai, C.L. Yu, H.S. Yu, Immunological dysfunction in chronic arsenic exposure: From subclinical condition to skin cancer, The Journal of dermatology, 45 (2018) 1271-1277.

[100] I. Khairul, Q.Q. Wang, Y.H. Jiang, C. Wang, H. Naranmandura, Metabolism, toxicity and anticancer activities of arsenic compounds, Oncotarget, 8 (2017) 23905.

[101] M. Banerjee, N. Banerjee, P. Ghosh, J.K. Das, S. Basu, A.K. Sarkar, J.C. States, A.K. Giri, Evaluation of the serum catalase and myeloperoxidase activities in chronic arsenic-exposed individuals and concomitant cytogenetic damage, Toxicology and applied pharmacology, 249 (2010) 47-54.

[102] M. Takahashi, T. Ishiko, H. Kamohara, H. Hidaka, O. Ikeda, M. Ogawa, H. Baba, Curcumin (1, 7-bis (4-hydroxy-3-methoxyphenyl)-1, 6-heptadiene-3, 5-dione) blocks the chemotaxis of neutrophils by inhibiting signal transduction through IL-8 receptors, Mediators of inflammation, 2007 (2007).

[103] A. Amalraj, A. Pius, S. Gopi, S. Gopi, Biological activities of curcuminoids, other biomolecules from turmeric and their derivatives-A review, Journal of traditional and complementary medicine, 7 (2017) 205-233.

[104] A. Sahebkar, Are curcuminoids effective C-reactive protein-lowering agents in clinical practice? Evidence from a meta-analysis, Phytotherapy research, 28 (2014) 633-642.

[105] Y. Panahi, N. Khalili, E. Sahebi, S. Namazi, M.S. Karimian, M. Majeed, A. Sahebkar, Antioxidant effects of curcuminoids in patients with type 2 diabetes mellitus: a randomized controlled trial, Inflammopharmacology, 25 (2017) 25-31.

[106] G. Liang, S. Yang, L. Jiang, Y. Zhao, L. Shao, J. Xiao, F. Ye, Y. Li, X. Li, Synthesis and anti-bacterial properties of mono-carbonyl analogues of curcumin, Chemical and Pharmaceutical Bulletin, 56 (2008) 162-167.

[107] Y. Panahi, P. Kianpour, R. Mohtashami, R. Jafari, L.E. Simental-Mendía, A. Sahebkar, Efficacy and Safety of Phytosomal Curcumin in Non-Alcoholic Fatty Liver Disease: A Randomized Controlled Trial, Drug Research, 67 (2017) 244-251.

[108] R. Rezaee, A.A. Momtazi, A. Monemi, A. Sahebkar, Curcumin: A potentially powerful tool to reverse cisplatin-induced toxicity, Pharmacological Research, 117 (2017) 218-227.

[109] P.D. Kasi, R. Tamilselvam, K. Skalicka-Woźniak, S.F. Nabavi, M. Daglia, A. Bishayee, H. Pazoki-toroudi, S.M. Nabavi, Molecular targets of curcumin for cancer therapy: an updated review, Tumor Biology, 37 (2016) 13017-13028.

[110] H. Zhou, C. S Beevers, S. Huang, The targets of curcumin, Current drug targets, 12 (2011) 332-347.

[111] M.S. Karimian, M. Pirro, M. Majeed, A. Sahebkar, Curcumin as a natural regulator of monocyte chemoattractant protein-1, Cytokine and Growth Factor Reviews, 33 (2017) 55-63.

[112] A.A. Momtazi, G. Derosa, P. Maffioli, M. Banach, A. Sahebkar, Role of microRNAs in the Therapeutic Effects of Curcumin in Non-Cancer Diseases, Molecular Diagnosis and Therapy, 20 (2016) 335-345.

[113] Y. Panahi, M.S. Hosseini, N. Khalili, E. Naimi, L.E. Simental-Mendía, M. Majeed, A. Sahebkar, Effects of curcumin on serum cytokine concentrations in subjects with metabolic syndrome: A post-hoc analysis of a randomized controlled trial, Biomedicine and Pharmacotherapy, 82 (2016) 578-582.

[114] L.R.C. Barclay, M.R. Vinqvist, K. Mukai, H. Goto, Y. Hashimoto, A. Tokunaga, H. Uno, On the antioxidant mechanism of curcumin: classical methods are needed to determine antioxidant mechanism and activity, Organic letters, 2 (2000) 2841-2843. 
[115] A. Sahebkar, M.-C. Serban, S. Ursoniu, M. Banach, Effect of curcuminoids on oxidative stress: A systematic review and meta-analysis of randomized controlled trials, Journal of functional foods, 18 (2015) 898-909.

[116] A.J. Ruby, G. Kuttan, K.D. Babu, K. Rajasekharan, R. Kuttan, Anti-tumour and antioxidant activity of natural curcuminoids, Cancer letters, 94 (1995) 79-83.

[117] N. Dhillon, B.B. Aggarwal, R.A. Newman, R.A. Wolff, A.B. Kunnumakkara, J.L. Abbruzzese, C.S. $\mathrm{Ng}, \mathrm{V}$. Badmaev, R. Kurzrock, Phase II trial of curcumin in patients with advanced pancreatic cancer, Clinical Cancer Research, 14 (2008) 4491-4499.

[118] Y.B. Pawar, H. Purohit, G.R. Valicherla, B. Munjal, S.V. Lale, S.B. Patel, A.K. Bansal, Novel lipid based oral formulation of curcumin: development and optimization by design of experiments approach, International journal of pharmaceutics, 436 (2012) 617-623.

[119] E. Balogun, M. Hoque, G. Pengfei, E. Killeen, C.J. Green, R. Foresti, A. Jawed, R. Motterlini, Curcumin activates the haem oxygenase-1 gene via regulation of Nrf2 and the antioxidant-responsive element, Biochemical Journal, 371 (2003) 887-895.

[120] N. Pescosolido, R. Giannotti, A.M. Plateroti, A. Pascarella, M. Nebbioso, Curcumin: therapeutical potential in ophthalmology, Planta medica, 80 (2014) 249-254.

[121] P. Qiu, J. Sun, S. Man, H. Yang, L. Ma, P. Yu, W. Gao, Curcumin attenuates $\mathrm{N}$-Nitrosodiethylamine-Induced liver injury in mice by utilizing the method of metabonomics, Journal of agricultural and food chemistry, 65 (2017) 2000-2007.

[122] J. Biswas, D. Sinha, S. Mukherjee, S. Roy, M. Siddiqi, M. Roy, Curcumin protects DNA damage in a chronically arsenic-exposed population of West Bengal, Human \& experimental toxicology, 29 (2010) 513-524.

[123] P. Pantazis, A. Varman, C. Simpson-Durand, J. Thorpe, S. Ramalingam, D. Subramaniam, C. Houchen, M. Ihnat, S. Anant, R.P. Ramanujam, Curcumin and turmeric attenuate arsenic-induced angiogenesis in ovo, Alternative Therapies in Health \& Medicine, 16 (2010).

[124] A. Kumari, D. Dash, R. Singh, Lipopolysaccharide (LPS) exposure differently affects allergic asthma exacerbations and its amelioration by intranasal curcumin in mice, Cytokine, 76 (2015) 334-342.

[125] S. Gao, X. Duan, X. Wang, D. Dong, D. Liu, X. Li, G. Sun, B. Li, Curcumin attenuates arsenic-induced hepatic injuries and oxidative stress in experimental mice through activation of Nrf2 pathway, promotion of arsenic methylation and urinary excretion, Food and chemical toxicology, 59 (2013) 739-747.

[126] R. Zhao, B. Yang, L. Wang, P. Xue, B. Deng, G. Zhang, S. Jiang, M. Zhang, M. Liu, J. Pi, Curcumin protects human keratinocytes against inorganic arsenite-induced acute cytotoxicity through an NRF2-dependent mechanism, Oxidative medicine and cellular longevity, 2013 (2013).

[127] M.V.B. Reddy, P. Sasikala, A. Karthik, S. Sudheer, L. Murthy, Protective role of curcumin against arsenic trioxide toxicity during gestation and lactational periods, chemotherapy, 2 (2012) 3.

[128] R.S. Yadav, R.K. Shukla, M.L. Sankhwar, D.K. Patel, R.W. Ansari, A.B. Pant, F. Islam, V.K. Khanna, Neuroprotective effect of curcumin in arsenic-induced neurotoxicity in rats, Neurotoxicology, 31 (2010) 533-539.

[129] P. Sankar, A.G. Telang, S. Suresh, M. Kesavan, K. Kannan, R. Kalaivanan, S.N. Sarkar, Immunomodulatory effects of nanocurcumin in arsenic-exposed rats, International immunopharmacology, 17 (2013) 65-70.

[130] P. Kushwaha, A. Yadav, M. Samim, S. Flora, Combinatorial drug delivery strategy employing nano-curcumin and nano-MiADMSA for the treatment of arsenic intoxication in mouse, Chemico-biological interactions, 286 (2018) 78-87.

[131] G.R. Prasad, N.F. Rossi, Arsenic intoxication associated with tubulointerstitial nephritis, American journal of kidney diseases, 26 (1995) 373-376.

[132] J.H. Miner, The glomerular basement membrane, Experimental cell research, 318 (2012) 973-978. 
[133] W.-T. Liao, K.-L. Chang, C.-L. Yu, G.-S. Chen, L.W. Chang, H.-S. Yu, Arsenic induces human keratinocyte apoptosis by the FAS/FAS ligand pathway, which correlates with alterations in nuclear factor- $\kappa \mathrm{B}$ and activator protein-1 activity, Journal of investigative dermatology, 122 (2004) 125-129. [134] H.R. Momeni, N. Eskandari, Effect of curcumin on kidney histopathological changes, lipid peroxidation and total antioxidant capacity of serum in sodium arsenite-treated mice, Experimental and toxicologic pathology, 69 (2017) 93-97.

[135] P. Sankar, A.G. Telang, R. Kalaivanan, V. Karunakaran, S. Suresh, M. Kesavan, Oral nanoparticulate curcumin combating arsenic-induced oxidative damage in kidney and brain of rats, Toxicology and industrial health, 32 (2016) 410-421.

[136] N. Tirkey, G. Kaur, G. Vij, K. Chopra, Curcumin, a diferuloylmethane, attenuates cyclosporine-induced renal dysfunction and oxidative stress in rat kidneys, BMC pharmacology, 5 (2005) 15.

[137] P.N. Saxena, S. Anand, N. Saxena, P. Bajaj, Effect of arsenic trioxide on renal functions and its modulation by Curcuma aromatica leaf extract in albino rat, Journal of environmental biology, 30 (2009).

[138] H.V. Patel, K. Kalia, Sub-chronic arsenic exposure aggravates nephrotoxicity in experimental diabetic rats, (2010).

[139] A. De Vizcaya-Ruiz, O. Barbier, R. Ruiz-Ramos, M.E. Cebrian, Biomarkers of oxidative stress and damage in human populations exposed to arsenic, Mutation Research/Genetic Toxicology and Environmental Mutagenesis, 674 (2009) 85-92.

[140] N. Dwivedi, S.J. Flora, Concomitant exposure to arsenic and organophosphates on tissue oxidative stress in rats, Food and chemical toxicology, 49 (2011) 1152-1159.

[141] A. Manimaran, S.N. Sarkar, P. Sankar, Influence of repeated preexposure to arsenic on acetaminophen-induced oxidative stress in liver of male rats, Food and chemical toxicology, 48 (2010) 605-610.

[142] S. Flora, S. Bhadauria, G. Kannan, N. Singh, Arsenic induced oxidative stress and the role of antioxidant supplementation during chelation: a review, Journal of Environmental Biology, 28 (2007) 333.

[143] T. Todorova, S. Vuilleumier, A. Kujumdzieva, Role of glutathione s-transferases and glutathione in arsenic and peroxide resistance in Saccharomyces cerevisiae: a reverse genetic analysis approach, Biotechnology \& Biotechnological Equipment, 21 (2007) 348-352.

[144] C.M. Grant, Role of the glutathione/glutaredoxin and thioredoxin systems in yeast growth and response to stress conditions, Molecular microbiology, 39 (2001) 533-541.

[145] M. Afzal, A. Afzal, A. Jones, D. Armstrong, A rapid method for the quantification of GSH and GSSG in biological samples, in: Oxidative Stress Biomarkers and Antioxidant Protocols, Springer, 2002, pp. 117-122.

[146] L. Pari, D.R. Amali, Protective role of tetrahydrocurcumin (THC) an active principle of turmeric on chloroquine induced hepatotoxicity in rats, J Pharm Pharm Sci, 8 (2005) 115-123.

[147] H.H. Cohly, A. Taylor, M.F. Angel, A.K. Salahudeen, Effect of turmeric, turmerin and curcumin on H2O2-induced renal epithelial (LLC-PK1) cell injury, Free Radical Biology and Medicine, 24 (1998) 49-54.

[148] F.M. El-Demerdash, M.I. Yousef, F.M. Radwan, Ameliorating effect of curcumin on sodium arsenite-induced oxidative damage and lipid peroxidation in different rat organs, Food and Chemical Toxicology, 47 (2009) 249-254.

[149] T. Hayakawa, Y. Kobayashi, X. Cui, S. Hirano, A new metabolic pathway of arsenite: arsenic-glutathione complexes are substrates for human arsenic methyltransferase Cyt19, Archives of toxicology, 79 (2005) 183-191.

[150] B.K. Mandal, Y. Ogra, K. Anzai, K.T. Suzuki, Speciation of arsenic in biological samples, Toxicology and applied pharmacology, 198 (2004) 307-318. 
[151] X.-J. Qin, L.G. Hudson, W. Liu, G.S. Timmins, K.J. Liu, Low concentration of arsenite exacerbates UVR-induced DNA strand breaks by inhibiting PARP-1 activity, Toxicology and applied pharmacology, 232 (2008) 41-50.

[152] J. Mo, Y. Xia, Z. Ning, T.J. Wade, J.L. Mumford, Elevated human telomerase reverse transcriptase gene expression in blood cells associated with chronic arsenic exposure in Inner Mongolia, China, Environmental health perspectives, 117 (2008) 354-360.

[153] S. Mukherjee, M. Roy, S. Dey, R.K. Bhattacharya, A mechanistic approach for modulation of arsenic toxicity in human lymphocytes by curcumin, an active constituent of medicinal herb Curcuma longa Linn, Journal of clinical biochemistry and nutrition, 41 (2007) 32-42.

[154] H. Tiwari, M.V. Rao, Curcumin supplementation protects from genotoxic effects of arsenic and fluoride, Food and chemical toxicology, 48 (2010) 1234-1238.

[155] M. Roy, D. Sinha, S. Mukherjee, J. Biswas, Curcumin prevents DNA damage and enhances the repair potential in a chronically arsenic-exposed human population in West Bengal, India, European Journal of Cancer Prevention, 20 (2011) 123-131.

[156] P. Sankar, A.G. Telang, K. Ramya, K. Vijayakaran, M. Kesavan, S.N. Sarkar, Protective action of curcumin and nano-curcumin against arsenic-induced genotoxicity in rats in vivo, Molecular biology reports, 41 (2014) 7413-7422.

[157] S.K. Niture, C.S. Velu, Q.R. Smith, G.J. Bhat, K.S. Srivenugopal, Increased expression of the MGMT repair protein mediated by cysteine prodrugs and chemopreventative natural products in human lymphocytes and tumor cell lines, Carcinogenesis, 28 (2007) 378-389.

[158] A. Rajeswari, Curcumin protects mouse brain from oxidative stress caused by 1-methyl-4-phenyl-1, 2, 3, 6-tetrahydro pyridine, European Review for Medical and Pharmacological Sciences, 10 (2006) 157.

[159] R. Motterlini, R. Foresti, R. Bassi, C.J. Green, Curcumin, an antioxidant and anti-inflammatory agent, induces heme oxygenase- 1 and protects endothelial cells against oxidative stress, Free Radical Biology and Medicine, 28 (2000) 1303-1312.

[160] J. Biswas, S. Roy, S. Mukherjee, D. Sinha, M. Roy, Indian spice curcumin may be an effective strategy to combat the genotoxicity of arsenic in Swiss albino mice, Asian Pac J Cancer Prev, 11 (2010) 239-247.

[161] D. Sinha, S. Mukherjee, S. Roy, R. Bhattacharya, M. Roy, Modulation of arsenic induced genotoxicity by curcumin in human lymphocytes, J Environ Chem Ecotoxicol, 1 (2009) 1-11.

[162] N. Tripathi, G. Kannan, B. Pant, D. Jaiswal, P. Malhotra, S. Flora, Arsenic-induced changes in certain neurotransmitter levels and their recoveries following chelation in rat whole brain, Toxicology letters, 92 (1997) 201-208.

[163] R.S. Yadav, M.L. Sankhwar, R.K. Shukla, R. Chandra, A.B. Pant, F. Islam, V.K. Khanna, Attenuation of arsenic neurotoxicity by curcumin in rats, Toxicology and applied pharmacology, 240 (2009) 367-376.

[164] V. Rodriguez, M. Jimenez-Capdeville, M. Giordano, The effects of arsenic exposure on the nervous system, Toxicology letters, 145 (2003) 1-18.

[165] O.S. von Ehrenstein, S. Poddar, Y. Yuan, D.G. Mazumder, B. Eskenazi, A. Basu, M. Hira-Smith, N. Ghosh, S. Lahiri, R. Haque, Children's intellectual function in relation to arsenic exposure, Epidemiology, 18 (2007) 44-51.

[166] J. Brinkel, M. Khan, A. Kraemer, A systematic review of arsenic exposure and its social and mental health effects with special reference to Bangladesh, International journal of environmental research and public health, 6 (2009) 1609-1619.

[167] U. Namgung, Z. Xia, Arsenic induces apoptosis in rat cerebellar neurons via activation of JNK3 and p38 MAP kinases, Toxicology and applied pharmacology, 174 (2001) 130-138.

[168] S.V. Jadhav, E. Bringas, G.D. Yadav, V.K. Rathod, I. Ortiz, K.V. Marathe, Arsenic and fluoride contaminated groundwaters: a review of current technologies for contaminants removal, Journal of Environmental Management, 162 (2015) 306-325. 
[169] W.C. Prozialeck, J.R. Edwards, D.W. Nebert, J.M. Woods, A. Barchowsky, W.D. Atchison, The vascular system as a target of metal toxicity, Toxicological Sciences, 102 (2007) 207-218.

[170] J. Li, S.B. Waters, Z. Drobna, V. Devesa, M. Styblo, D.J. Thomas, Arsenic (+ 3 oxidation state) methyltransferase and the inorganic arsenic methylation phenotype, Toxicology and applied pharmacology, 204 (2005) 164-169.

[171] M. Bishnoi, K. Chopra, S.K. Kulkarni, Protective effect of Curcumin, the active principle of turmeric (Curcuma longa) in haloperidol-induced orofacial dyskinesia and associated behavioural, biochemical and neurochemical changes in rat brain, Pharmacology Biochemistry and Behavior, 88 (2008) 511-522.

[172] P.K. Shukla, V.K. Khanna, M.M. Ali, M.Y. Khan, R.C. Srimal, Anti-ischemic effect of curcumin in rat brain, Neurochemical research, 33 (2008) 1036-1043.

[173] M. Thiyagarajan, S.S. Sharma, Neuroprotective effect of curcumin in middle cerebral artery occlusion induced focal cerebral ischemia in rats, Life sciences, 74 (2004) 969-985.

[174] S. Daniel, J.L. Limson, A. Dairam, G.M. Watkins, S. Daya, Through metal binding, curcumin protects against lead-and cadmium-induced lipid peroxidation in rat brain homogenates and against lead-induced tissue damage in rat brain, Journal of inorganic biochemistry, 98 (2004) 266-275.

[175] M. Garcia-Alloza, L. Borrelli, A. Rozkalne, B. Hyman, B. Bacskai, Curcumin labels amyloid pathology in vivo, disrupts existing plaques, and partially restores distorted neurites in an Alzheimer mouse model, Journal of neurochemistry, 102 (2007) 1095-1104.

[176] A.J. Jahan-Abad, P. Morteza-Zadeh, S.S. Negah, A. Gorji, Curcumin attenuates harmful effects of arsenic on neural stem/progenitor cells, Avicenna journal of phytomedicine, 7 (2017) 376.

[177] Z. Xiao, A. Zhang, J. Lin, Z. Zheng, X. Shi, W. Di, W. Qi, Y. Zhu, G. Zhou, Y. Fang, Telomerase: a target for therapeutic effects of curcumin and a curcumin derivative in A $\beta$ 1-42 insult in vitro, PLoS One, 9 (2014) e101251.

[178] M. Fallah, N. Moghble, I. Javadi, H. Bahadoran, A. Shahriary, Effect of Curcumin and $\mathrm{N}$-Acetylcysteine on Brain Histology and Inflammatory Factors (MMP-2, 9 and TNF- $\alpha$ ) in Rats Exposed to Arsenic, Pharmaceutical Sciences, 24 (2018) 264.

[179] P. Srivastava, Y.K. Dhuriya, R. Gupta, R.K. Shukla, R.S. Yadav, H.N. Dwivedi, A.B. Pant, V.K. Khanna, Protective effect of curcumin by modulating BDNF/DARPP32/CREB in arsenic-induced alterations in dopaminergic signaling in rat corpus striatum, Molecular neurobiology, 55 (2018) 445-461.

[180] P. Srivastava, Y.K. Dhuriya, V. Kumar, A. Srivastava, R. Gupta, R.K. Shukla, R.S. Yadav, H.N. Dwivedi, A.B. Pant, V.K. Khanna, PI3K/Akt/GSK3 $\beta$ induced CREB activation ameliorates arsenic mediated alterations in NMDA receptors and associated signaling in rat hippocampus: Neuroprotective role of curcumin, Neurotoxicology, 67 (2018) 190-205.

[181] S.J. Flora, K. Bhatt, A. Mehta, Arsenic moiety in gallium arsenide is responsible for neuronal apoptosis and behavioral alterations in rats, Toxicology and applied pharmacology, 240 (2009) 236-244.

[182] S.-X. Wang, Z.-H. Wang, X.-T. Cheng, J. Li, Z.-P. Sang, X.-D. Zhang, L.-L. Han, X.-Y. Qiao, Z.-M. $\mathrm{Wu}, \mathrm{Z}$.-Q. Wang, Arsenic and fluoride exposure in drinking water: children's IQ and growth in Shanyin county, Shanxi province, China, Environmental health perspectives, 115 (2007) 643-647.

[183] S. Zarazúa, S. Bürger, J.M. Delgado, M.E. Jiménez-Capdeville, R. Schliebs, Arsenic affects expression and processing of amyloid precursor protein (APP) in primary neuronal cells overexpressing the Swedish mutation of human APP, International Journal of Developmental Neuroscience, 29 (2011) 389-396.

[184] S. Gharibzadeh, S.S. Hoseini, Arsenic exposure may be a risk factor for Alzheimer's disease, The Journal of neuropsychiatry and clinical neurosciences, 20 (2008) 501-501.

[185] G. Gong, S.E. O'Bryant, The arsenic exposure hypothesis for Alzheimer disease, Alzheimer Disease \& Associated Disorders, 24 (2010) 311-316. 
[186] R.S. Yadav, L.P. Chandravanshi, R.K. Shukla, M.L. Sankhwar, R.W. Ansari, P.K. Shukla, A.B. Pant, V.K. Khanna, Neuroprotective efficacy of curcumin in arsenic induced cholinergic dysfunctions in rats, Neurotoxicology, 32 (2011) 760-768.

[187] D.L. Stankowska, V.R. Krishnamoorthy, D.Z. Ellis, R.R. Krishnamoorthy, Neuroprotective effects of curcumin on endothelin-1 mediated cell death in hippocampal neurons, Nutritional neuroscience, 20 (2017) 273-283.

[188] P. Srivastava, R.S. Yadav, L.P. Chandravanshi, R.K. Shukla, Y.K. Dhuriya, L.K. Chauhan, H.N. Dwivedi, A.B. Pant, V.K. Khanna, Unraveling the mechanism of neuroprotection of curcumin in arsenic induced cholinergic dysfunctions in rats, Toxicology and Applied Pharmacology, 279 (2014) 428-440.

[189] E. Marafante, M. Vahter, J. Envall, The role of the methylation in the detoxication of arsenate in the rabbit, Chemico-biological interactions, 56 (1985) 225-238.

[190] M. Styblo, Z. Drobna, I. Jaspers, S. Lin, D. Thomas, The role of biomethylation in toxicity and carcinogenicity of arsenic: a research update Environ Health Perspect 110 (suppl 5): 767-771, Find this article online, (2002).

[191] D.G. Mazumder, Effect of chronic intake of arsenic-contaminated water on liver, Toxicology and applied pharmacology, 206 (2005) 169-175.

[192] Y. Xie, K.J. Trouba, J. Liu, M.P. Waalkes, D.R. Germolec, Biokinetics and subchronic toxic effects of oral arsenite, arsenate, monomethylarsonic acid, and dimethylarsinic acid in $\mathrm{v}$-Ha-ras transgenic (Tg. AC) mice, Environmental health perspectives, 112 (2004) 1255-1263.

[193] S. Flora, R. Gupta, Beneficial effects of Centella asiatica aqueous extract against arsenic-induced oxidative stress and essential metal status in rats, Phytotherapy Research, 21 (2007) 980-988.

[194] T.-T. Phan, P. See, S.-T. Lee, S.-Y. Chan, Protective effects of curcumin against oxidative damage on skin cells in vitro: its implication for wound healing, Journal of Trauma and Acute Care Surgery, 51 (2001) 927-931.

[195] V. Mathews, P. Binu, M.S. Paul, M. Abhilash, A. Manju, R.H. Nair, Hepatoprotective efficacy of curcumin against arsenic trioxide toxicity, Asian Pacific Journal of Tropical Biomedicine, 2 (2012) S706-S711.

[196] A. Yadav, V. Lomash, M. Samim, S.J. Flora, Curcumin encapsulated in chitosan nanoparticles: a novel strategy for the treatment of arsenic toxicity, Chemico-biological interactions, 199 (2012) 49-61.

[197] P. Sankar, A. Gopal Telang, R. Kalaivanan, V. Karunakaran, K. Manikam, S.N. Sarkar, Effects of nanoparticle-encapsulated curcumin on arsenic-induced liver toxicity in rats, Environmental toxicology, 30 (2015) 628-637.

[198] R. Karmakar, T. Mondal, B. Saha, D.K. Ban, B. Dey, P.G. Dastidar, R. Goswami, Arsenic induced Biochemical perturbation in Swiss albino mice and cytoprotective activities of Curcumin, International Journal of Environmental Sciences, 2 (2011) 228.

[199] L. Leung, M. Kwong, S. Hou, C. Lee, J.Y. Chan, Deficiency of the Nrf1 and Nrf2 transcription factors results in early embryonic lethality and severe oxidative stress, Journal of Biological Chemistry, 278 (2003) 48021-48029.

[200] T. Nguyen, P.J. Sherratt, C.B. Pickett, Regulatory mechanisms controlling gene expression mediated by the antioxidant response element, Annual review of pharmacology and toxicology, 43 (2003) 233-260.

[201] S. Khan, J.A. Vala, S.U. Nabi, G. Gupta, D. Kumar, A.G. Telang, J. Malik, Protective effect of curcumin against arsenic-induced apoptosis in murine splenocytes in vitro, Journal of immunotoxicology, 9 (2012) 148-159.

[202] M. Muthumani, S. Miltonprabu, Ameliorative efficacy of tetrahydrocurcumin against arsenic induced oxidative damage, dyslipidemia and hepatic mitochondrial toxicity in rats, Chemico-biological interactions, 235 (2015) 95-105. 
[203] M. Muthumani, Tetrahydrocurcumin potentially attenuates arsenic induced oxidative hepatic dysfunction in rats, J Clin Toxicol, 3 (2013) 2161-0495.1000168.

[204] S. Chattopadhyay, S. Maiti, G. Maji, B. Deb, B. Pan, D. Ghosh, Protective role of Moringa oleifera (Sajina) seed on arsenic-induced hepatocellular degeneration in female albino rats, Biological trace element research, 142 (2011) 200-212.

[205] M. Ahadi, V. Naseh, M. Salehipour, The HER-2 as a Target Gene of Curcumin to Protect Hepatocytes Against the Arsenic-induced Carcinoma in Mice, Iranian journal of pathology, 12 (2017) 158.

[206] Y. An, Z. Gao, Z. Wang, S. Yang, J. Liang, Y. Feng, K. Kato, M. Nakano, S. Okada, K. Yamanaka, Immunohistochemical analysis of oxidative DNA damage in arsenic-related human skin samples from arsenic-contaminated area of China, Cancer letters, 214 (2004) 11-18.

[207] Y. Qian, C. Chen, Q. Zhang, Y. Li, Z. Chen, M. Li, Concentrations of cadmium, lead, mercury and arsenic in Chinese market milled rice and associated population health risk, Food control, 21 (2010) 1757-1763.

[208] D.O. Rocha-Amador, J. Calderón, L. Carrizales, R. Costilla-Salazar, I.N. Pérez-Maldonado, Apoptosis of peripheral blood mononuclear cells in children exposed to arsenic and fluoride, Environmental toxicology and pharmacology, 32 (2011) 399-405.

[209] A.S. Andrew, D.A. Jewell, R.A. Mason, M.L. Whitfield, J.H. Moore, M.R. Karagas, Drinking-water arsenic exposure modulates gene expression in human lymphocytes from a US population, Environmental health perspectives, 116 (2008) 524-531.

[210] S. Biswas, C. Maji, P.K. Sarkar, S. Sarkar, A. Chattopadhyay, T.K. Mandal, Ameliorative effect of two Ayurvedic herbs on experimentally induced arsenic toxicity in calves, Journal of ethnopharmacology, 197 (2017) 266-273.

[211] A. Prakash, S. Khan, D. Kumar, A.G. Telang, J.K. Malik, Concurrent administration of curcumin mitigates arsenic-and chlorpyrifos-induced apoptosis in rat thymocytes, Adv Anim Vet Sci, 2 (2014) 407-413.

[212] X.-N. Wang, C.-J. Zhang, H.-L. Diao, Y. Zhang, Protective effects of curcumin against sodium arsenite-induced ovarian oxidative injury in a mouse model, Chinese medical journal, 130 (2017) 1026.

[213] H. Perveen, S. Chattopadhyay, M. Maity, M. Dash, S.S. Islam, Involvement of proinflammatory cytokines and metallothionein in the repairing of arsenic-mediated uterine tissue damage by curcumin, Journal of basic and clinical physiology and pharmacology, (2019).

[214] M.C. Perker, B. Orta Yilmaz, N. Yildizbayrak, Y. Aydin, M. Erkan, Protective effects of curcumin on biochemical and molecular changes in sodium arsenite-induced oxidative damage in embryonic fibroblast cells, Journal of biochemical and molecular toxicology, (2019) e22320.

[215] A. Goel, A.B. Kunnumakkara, B.B. Aggarwal, Curcumin as "Curecumin": from kitchen to clinic, Biochemical pharmacology, 75 (2008) 787-809. 